\title{
Migration and Land Use Change in Europe: A Review
}

\author{
Simon Bell \\ OPENspace Research Centre, Edinburgh College of Art, \\ Lauriston Place, Edinburgh EH3 9DF, UK and \\ Estonian University of Life Sciences, Kreutzwaldi 5, 51014 Tartu, Estonia \\ email: s.bell@eca.ac.uk \\ http://www.openspace.eca.ac.uk/ \\ Susana Alves \\ OPENspace Research Centre, Edinburgh College of Art, \\ Lauriston Place, Edinburgh EH3 9DF, UK \\ email: s.alves@eca.ac.uk \\ Eva Silveirinha de Oliveira \\ OPENspace Research Centre, Edinburgh College of Art, \\ Lauriston Place, Edinburgh EH3 9DF, UK \\ email: eva.m.oliveira@eca.ac.uk

\section{Affonso Zuin} \\ OPENspace Research Centre, Edinburgh College of Art, \\ Lauriston Place, Edinburgh EH3 9DF, UK and \\ DFT, Federal University of Viçosa, \\ 36570-000, Viçosa, MG, Brazil \\ email: a.zuin@eca.ac.uk
}

Accepted on 7 July 2010

Published on 28 August 2010

\begin{abstract}
Migration within Europe and between Europe and other parts of the world is a major driver of population change and has far reaching effects on land use. The theory, historical trends and actual patterns of migration were reviewed and from these an understanding of different categories of migration was developed. The pressures for land use change caused by different types of migration were developed and interpreted into a map of Europe, resolved at NUTSx level and a set of descriptions of land use change projections, examples of which are presented. The paper suggests that the implications of migration on land use change need further research and better data in order to be able to be more certain of trends. In the modern world migration will continue to be a major influence on land use and European policies which consider migration and land use as separate issues are likely to miss important connections.
\end{abstract}

Keywords: Push-pull factors, International retirement migration, DPSIR, Urbanisation, Land use change, NUTS, Europe

This review is licensed under a Creative Commons Attribution-Non-Commercial-NoDerivs 3.0 Germany License. http://creativecommons.org/licenses/by-nc-nd/3.0/de/ 


\section{Imprint / Terms of Use}

Living Reviews in Landscape Research is a peer reviewed open access journal published by the Leibniz Centre for Agricultural Landscape Research (ZALF), Eberswalder Straße 84, 15374 Müncheberg, Germany. ISSN 1863-7329.

This review is licensed under a Creative Commons Attribution-Non-Commercial-NoDerivs 3.0 Germany License: http://creativecommons.org/licenses/by-nc-nd/3.0/de/

Because a Living Reviews article can evolve over time, we recommend to cite the article as follows:

Simon Bell, Susana Alves, Eva Silveirinha de Oliveira and Affonso Zuin, "Migration and Land Use Change in Europe: A Review",

Living Rev. Landscape Res., 4, (2010), 2. [Online Article]: cited [<date $>$ ], http://www.livingreviews.org/lrlr-2010-2

The date given as $<$ date $>$ then uniquely identifies the version of the article you are referring to.

\section{Article Revisions}

Living Reviews supports two ways of keeping its articles up-to-date:

Fast-track revision A fast-track revision provides the author with the opportunity to add short notices of current research results, trends and developments, or important publications to the article. A fast-track revision is refereed by the responsible subject editor. If an article has undergone a fast-track revision, a summary of changes will be listed here.

Major update A major update will include substantial changes and additions and is subject to full external refereeing. It is published with a new publication number.

For detailed documentation of an article's evolution, please refer to the history document of the article's online version at http: //www.livingreviews.org/lrlr-2010-2. 


\section{Contents}

1 Introduction $\quad 5$

2 Migration and its role in landscape change: previous studies 6

2.1 Migration: Definitions . . . . . . . . . . . . . . . . . 7

2.2 Environmental support in the context of migration: The role of push and pull factors 7

3 Historical patterns and processes of migration $\quad 13$

3.1 Phases of migration . . . . . . . . . . . . . . . . . . . . 13

4 Types of migration $\quad 16$

4.1 Labour migration in the $\mathrm{EU} \ldots \ldots \ldots$. . . . . . . . . . . . . . . . . . . . . . . . . . . . . . .

4.1 .1 Highly skilled labour migration . . . . . . . . . . . . . . . . . . . . . . . . . . . . . . . . . . 16

4.1.2 Unskilled low wage labour and temporary migration . . . . . . . . . . 16

4.2 Forced migration . . . . . . . . . . . . . . . . . . . . . 17

4.3 International retirement migration $(\mathrm{IRM}) \ldots \ldots \ldots \ldots$

4.4 Internal migration . . . . . . . . . . . . . . . . . . . . 18

5 Characteristics of immigrants in urban areas $\quad \mathbf{2 0}$

6 Predicted migration and resulting population changes $\quad 22$

7 Land use change processes resulting from migration pressures $\quad 28$

8 Projected effects of migration pressures on land use change at NUTSx 30

8.1 Land abandonment in Latvia as a result of out-migration . . . . . . . . . . . . . 34

8.2 Suburbanisation of the rural coastal landscape in Spain as a result of international retirement migration . . . . . . . . . . . . . . . . . . . . . 34

8.3 Urban growth in Lisbon as a result of immigration . . . . . . . . . . . . . 37

9 Conclusions $\quad 41$

$\begin{array}{ll}\text { References } & 43\end{array}$

\section{List of Tables}

1 Examples of push factors (from the literature review) supporting the model . . . . 9

Examples of pull factors (from the literature) supporting the model . . . . . . . . . 9

Examples of observable changes in land use (from the literature) supporting the model 10

Push and pull factors affecting migration in relation to specific countries . . . . . . 11

Current land use change processes as a result directly or indirectly of different types

of migration in Europe . . . . . . . . . . . . . . . . . . 31 



\section{Introduction}

This review paper derives from work undertaken as part of the EU Fifth Framework Integrated Project PLUREL - Peri-Urban Land Use Change. It is based on a review of the theory and processes of migration, drawing on a wide range of literature, and uses secondary qualitative analysis of data to develop projections of land use change and condition resolved to a spatial scale known as NUTSx ${ }^{1}$. It reviews the nature of the phenomenon of migration in Europe to understand how different types and patterns of migration within and between European countries as well as from outside Europe have affected and are likely to continue to affect land use change. Change in land use may vary from increasing urban densification, urbanisation and urban sprawl to rural abandonment and extensification. This variation in land use change is related to migration flows, which work in several directions, at different territorial scales and involve different socio-economic groups - not being entirely associated with poor or unskilled people, although these may form an overall majority. Even if we expect the intensity of land use changes to vary from country to country and region to region, due to data limitations it is very difficult to do so. Accordingly, the present analysis will focus on a single European territorial level - NUTSx (a hybrid territorial unit between NUTS 2 and 3 used for several EU projects including SENSOR and PLUREL), even though most of the data on migration is defined at NUTS 2. We also give examples of the variation within a single NUTS region to illustrate arguments and present examples of specific "hotspots" of in- or out-migration processes.

Two main gaps in the migration literature are, firstly, a lack of a clear link showing how data on migration is related to land use change, and secondly, the use of demographic trends, for example, based on levels of fertility and mortality rates, to give a prognosis of migration into the future. We try to address these gaps by making inferences and postulating hypotheses on the effect of migration on the landscape - based on data from land cover maps and field observation in affected areas and by considering important driving forces and factors, the way they affect migration change, and their subsequent contribution to land use change.

It is useful to relate studies of land use change to the so-called "DPSIR" framework (drivers, pressures, states, impact and response) (EEA) so that demographic, environmental, economic or technological drivers can be understood as setting the conditions leading to migration which then places pressures on the land (or a release of pressure) leading to a change of state (eg increased urbanisation, sprawl, land abandonment). This new state produces impacts on environmental services (such as reduction in green areas) or quality of life (such as increasing crime or commuting time) and which call for responses by national and local government (such as restricting certain types of migration or by reducing the impact).

The main objective of this paper is thus to review, identify and quantify (as far as possible with the data available) the range and type of migration pressures and to define these for the future in terms of anticipated land use changes at the NUTSx level. Data limitations demand that projected land use changes are mostly descriptive at this point owing to the quality of the data.

\footnotetext{
${ }^{1}$ NUTS stands for Nomenclature of Units for Territorial Statistics
} 


\section{Migration and its role in landscape change: previous stud- ies}

Landscape changes are dynamic over time due to natural processes and societal development (Bürgi et al., 2004; Wood and Handley, 2001). These changes in landscape patterns are influenced by a number of driving forces. According to Antrop's (2005) analysis of landscape changes that have taken place in course of the past centuries, there are three main social driving forces responsible for changes in the landscape: accessibility, urbanization and globalization. Other social drivers such as demography; technology; economy; political and social institutions; culturally determined attitudes, beliefs, and behaviour; information and its flow (Agarwal et al., 2003, p. 36) are also noted in the literature. Lambin et al. (2001) trying to summarize factors affecting landscape change have used the term "globalisation" as a unifying theme since it can increase or decrease the driving forces by connecting people, places, markets and information all over the world (Lambin et al., 2001, p. 266). What the literature on migration shows is that migration fluxes are one of the expressions of globalisation processes which occur at a national and international level and reflect the different economic and social policies of each country. While the connection between migration and urbanisation has been presented in the literature for specific areas, such as Spain (Zasada et al., 2010), it is less clear how accessibility and globalisation interact with migration. Even though these factors are not directly addressed in detail in this paper, the next section presents a conceptual framework which aims to structure the migration literature and to give directions for further research on the subject.

The review of the literature shows that flows of people moving from one place to another, in a voluntary or a forced way have always existed as a result of climate changes, wars, demographic growth, or economic reasons (Castles, 2000). Since the 16th century, demographic changes in Europe have also functioned as driving forces for landscape change (Antrop, 2005). Following a general trend of out-migration until 1945, the post war years and particularly the period from the 1980s until the present, international immigration levels in Europe increased, reaching particularly high levels in the 1990s and since (Boswell, 2005; Castles, 2000), due to the combination of a prolonged period of sustained economic growth (that ended in 2008), the fall of the Berlin Wall, which opened up Eastern Europe, the end of the Soviet Union (Godoy, 2002) and, since 2004, the expansion of the European Union and liberalisation of restrictions on movement within much of the EU.

The impact of migration on host societies has been widely discussed, mainly in terms of social and economic impacts rather than on landscape change, although, according to (Greenwood and Hunt, 2003, p. 3), urbanisation might have been responsible for raising the initial interest in migration processes by academics. During the transition from the 19 th to the 20th centuries in both the U.S. and in Western European, urbanisation grew quickly, mainly due to populations moving from the countryside to the cities and also because of the large numbers of immigrants arriving in American cities. By the 1920s, migration was being studied as a social and demographic phenomenon and the Great Depression in the 1930s was an incentive for economists to join other scholars on migration as a topic of research (Greenwood and Hunt, 2003). Recently, many scholars have been looking at this phenomenon from different perspectives, such as sociology, anthropology, politics and economics, leading to a fragmented view of migration (Borkert et al., 2006). However, studies regarding the impact of migration in land-use change are very limited (López et al., 2006), especially in the European context; recent work by the authors of this paper has started to redress this imbalance, examining some of the migration hotspots, for instance for retirement migration, and consequent landscape changes. Furthermore, it is important to note that while much migration is from rural to urban areas and hence the significant effect on land use change tends to be focused on urban areas, out-migration from rural areas also has a profound effect on land use change, as will be discussed in detail in Section 6 .

Living Reviews in Landscape Research

http://www. livingreviews . org/lrlr-2010-2 


\subsection{Migration: Definitions}

There is no single official definition of migration and the lack of agreement on how to define it between different countries and organisations is both significant and problematic for any international study. Different national statistical offices use different definitions when they are compiling census or migration data and this is an issue when trying to compare data and to provide a Europe-wide picture. For the purposes of this paper, migration is defined according to the International Migration Organisation (Perruchoud, 2004, p. 41) as: "A process of moving, either across an international border, or within a State. It is a population movement, encompassing any kind of movement of people, whatever its length, composition and cause".

Some of the theories on migration found in the literature focus on the initiation of international migration while others focus on the reasons why international migration continues over time and different conceptual frameworks are usually presented. For instance, the first model to explain the migratory movements was based on the Neoclassical Economic Theory (Arango, 2000). This model is based on international labour market inequalities, which generate wage differentials across borders (Kubursi, 2006; Massey, 2003). These inequalities lead to the movement of workers from areas with surplus of labour and low wages to countries, or regions, where there is demand for labour and where wages are higher. The premise behind the neoclassical theory, that an individual would move to improve his or her economic situation, is one of the bases for the "push-pull" model (Figueiredo, 2005; Peixoto, 2004). This framework perceives migration as a consequence of the interaction of "push" factors that motivate people to move and leave their places of origin, and "pull" factors that attract people to particular places (Portes, 1995). The "push factors" include demographic pressures, poverty or social and political hardship, while the "pull factors" can include the perceived economic, political and social prosperity or freedom of the prospective receiving country (Portes, 1995; Portes and Böröcz, 1989).

While we recognise the contribution of the neoclassical economic model as the source of some push and pull factors, we need to point out that there are many more factors, other than economic reasons, that can affect the actual pattern of migration, such as social, political and cultural conditions and past colonial history of both countries or regions (that which the migrants leave and that where they go). This paper therefore builds on the push-pull model but also brings the notion of 'environmental supportiveness' to the analysis of migration (Sugiyama and Ward Thompson, 2007) - or the extent to which environmental constraints and possibilities guide individual and collective decisions to migrate. This transactional concept is borrowed from environmental psychology and involves both personal and environmental factors giving us more possibilities to analyse issues of motivation, attractions and impediments in relation to migration in a more holistic way. The use of environmental supportiveness to conceptualise the relationship between migration and landscape also gives us the possibility of linking person-environment factors with the dynamic experience of the physical and spatial structure of the landscape.

\subsection{Environmental support in the context of migration: The role of push and pull factors}

The model used to explain and to predict migration trends builds on the notion of environmental support and highlights relevant push and push factors beyond the merely economic. These consist of one set of factors which tend to push a person into becoming a migrant and to leave their original place of residence and a second set of factors which pull them towards a certain destination as noted above. A typical example is related to unemployment or low wages which may act as a push factor to leave one place while a job market and higher wages in a specific region or country would act as the corresponding pull factor - clearly related to the neo-classical economic model. However, political repression could also act as a push factor leading someone to try to become an asylum 
seeker in a country seen as being easy to get into and where other pull factors include the presence of other people from the same ethnic and political group to offer support. This means that there are particular places which tend to have specific combinations of push factors and others with complementary pull factors leading to unequal trends of migration. Some countries such as the UK are very popular as destinations and others, such as Poland much less so for all kinds of migration. Likewise, some countries are noted for being sources of certain kinds of migrants, such as young labour migrants coming from Poland.

Figure 1 shows an example of how a combination of push and pull factors influences different classes of migrants to Portugal. This example is relevant because it shows distinct groups of people with specific reasons for migration which are also different from each other.

Tables 1-3 show how a number of different push and pull factors have been identified in the literature reviewed in this paper. From this it is possible to identify different categories of factors which allows the model to be applied in different settings and among different migrant groups. Table 4 shows this application for specific countries.

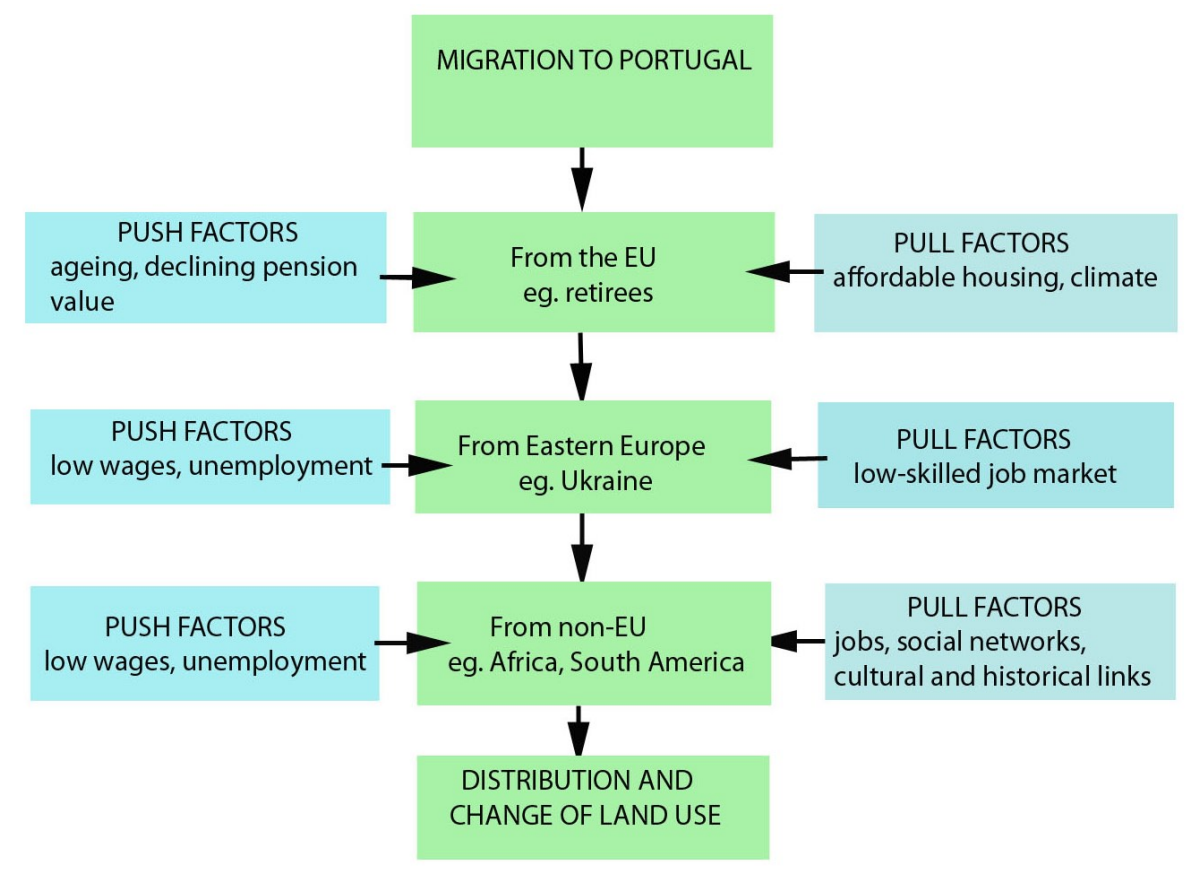

Figure 1: The push and pull migration model applied to Portugal.

As shown in Tables $1-3$, there is the need to acknowledge the multiplicity of factors influencing migration and its consequence on the landscape. When observed through the 'environmental supportiveness' lens, for instance, migration to sunbelt belt areas of Spain may provide support for retirees' personal projects in terms of access to an attractive outdoor lifestyle in a warm climate; however, it does not necessarily result in supportiveness for the ecology of these fragile landscapes resulting from the development of dense settlements close to the coastline. There is therefore, a fit in terms of people's desires and needs but a lack of fit in terms of management and conservation of the physical environment. 
Table 1: Examples of push factors (from the literature review) supporting the model

\begin{tabular}{|c|c|}
\hline \multicolumn{2}{|c|}{ Push Factors - Migration } \\
\hline Demographic growth & Portes (1995) \\
\hline Poverty & Portes and Böröcz (1989) \\
\hline Social and political hardship & \\
\hline $\begin{array}{l}\text { Investment in human capital - wish to } \\
\text { use skills elsewhere }\end{array}$ & Massey et al. (1993) \\
\hline $\begin{array}{l}\text { Cultural links between core areas } \\
\text { (cities) and peripheral areas }\end{array}$ & Massey et al. $(1993,2005)$ \\
\hline $\begin{array}{l}\text { Difficult living conditions in the city - } \\
\text { high stress levels, poor housing, high } \\
\text { crime levels, housing costs, poor trans- } \\
\text { port }\end{array}$ & Malgesini (2006); EEA (2006) \\
\hline Climate change & UNFPA (2007) \\
\hline Retirement & $\begin{array}{l}\text { Lardiés Bosque and Castro Romero } \\
\text { (2002); King et al. (1998) }\end{array}$ \\
\hline
\end{tabular}

Table 2: Examples of pull factors (from the literature) supporting the model

\begin{tabular}{|c|c|}
\hline \multicolumn{2}{|c|}{ Pull Factors - Migration } \\
\hline $\begin{array}{l}\text { Opportunities and an available labour } \\
\text { market for unskilled labour }\end{array}$ & $\begin{array}{l}\text { Malgesini (2006); Malheiros (2002); } \\
\text { Malheiros and Vala (2004); Fonseca } \\
\text { (2001) }\end{array}$ \\
\hline $\begin{array}{l}\text { Social networks, "co-ethical" networks, } \\
\text { use of human capital }\end{array}$ & $\begin{array}{l}\text { Deurloo and Musterd (1998); Bodaar } \\
\text { and Rath (2005); Hårsman (2006); } \\
\text { Malheiros and Vala (2004); Arapoglou } \\
\text { (2006) }\end{array}$ \\
\hline Lifestyle & $\begin{array}{l}\text { Lardiés Bosque and Castro Romero } \\
\text { (2002); King et al. (1998) }\end{array}$ \\
\hline Historical and cultural links & $\begin{array}{l}\text { Deurloo and Musterd (1998); Mal- } \\
\text { heiros (2002); Malheiros and Vala } \\
(2004)\end{array}$ \\
\hline $\begin{array}{l}\text { Globalisation and transnational coop- } \\
\text { eration }\end{array}$ & Favell (2003); White (1998) \\
\hline $\begin{array}{l}\text { Exodus of local population from rural } \\
\text { areas }\end{array}$ & $\begin{array}{l}\text { ICFTU (2003); Labrianidis and Sykas } \\
(2009)\end{array}$ \\
\hline
\end{tabular}


Table 3: Examples of observable changes in land use (from the literature) supporting the model

\begin{tabular}{ll}
\hline \multicolumn{2}{c}{ Changes in distribution and use of land } \\
\hline Urbanisation & Malgesini (2006); Bodaar and Rath \\
& $(2005) ;$ Rodríguez et al. (1998); Ara- \\
& poglou (2006); King et al. (1998) \\
\hline Suburbanisation and urban sprawl & Malheiros (2002); Malheiros and Vala \\
& $(2004) ;$ Arapoglou (2006) \\
\hline Concentration of migrants in specific & Fonseca (2001); Arapoglou (2006); \\
sectors of a city & Bodaar and Rath (2005); Hårsman \\
& (2006); Favell (2003) \\
\hline Landscape change of coastal areas & Rodríguez et al. (1998); Petrov and \\
& Lavalle (2006); King et al. (1998) \\
\hline Construction in rural areas & EEA (2006) \\
\hline Changes in agricultural land- & Labrianidis and Sykas (2009) \\
scapes (extensive into intensive & \\
agriculture/changes in the type of & \\
species/products) & \\
\hline
\end{tabular}




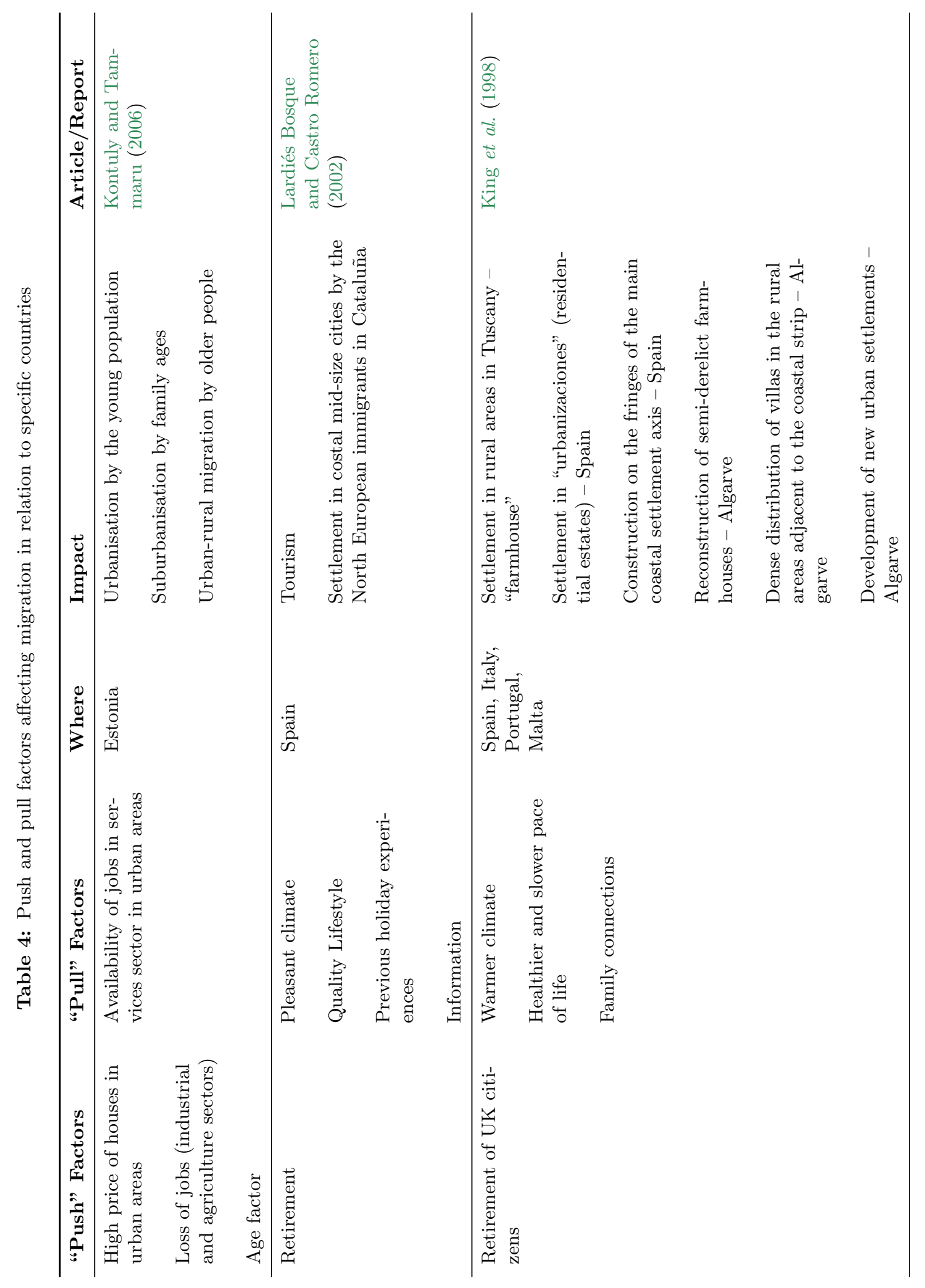




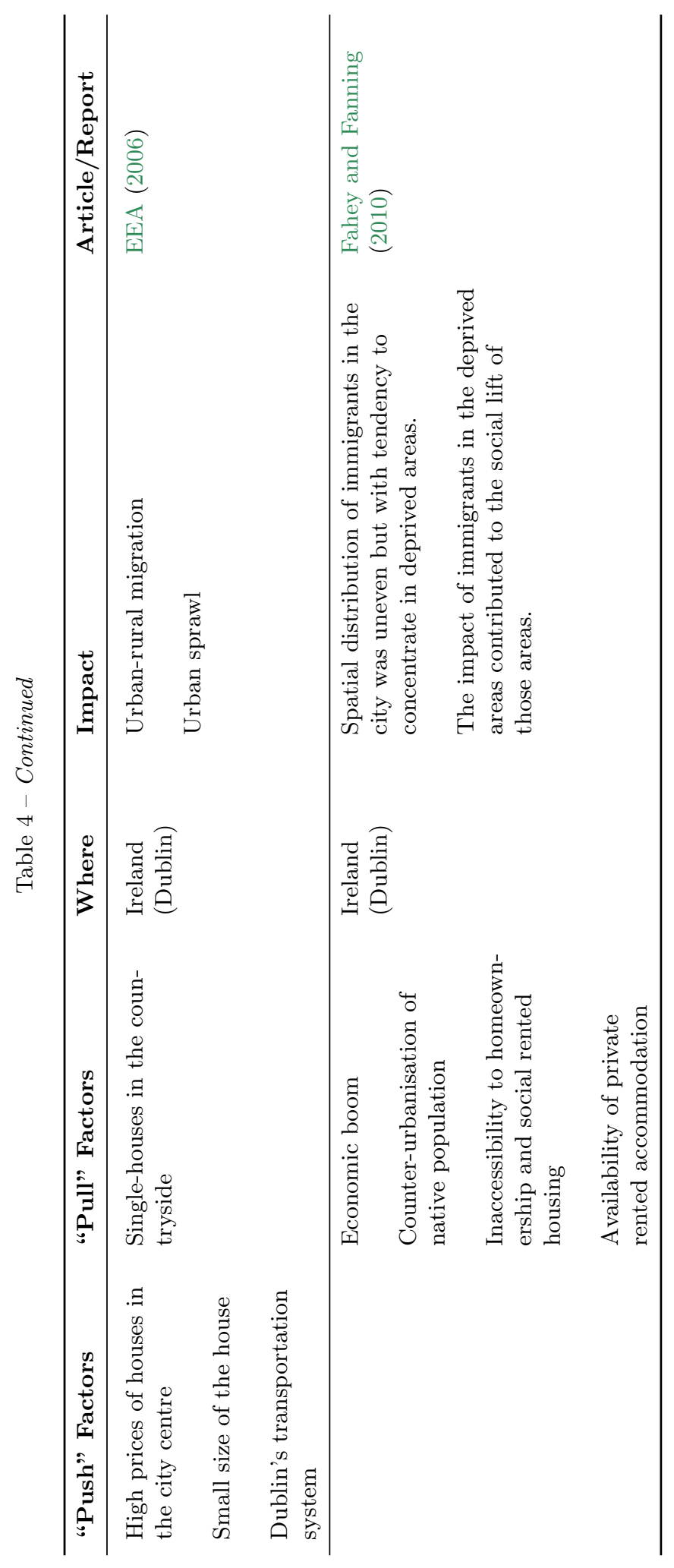




\section{Historical patterns and processes of migration}

Europe has been characterised by large scale migration events and processes throughout history. These complex migratory movements occurred not only between European countries but also between Europe and the rest of the World (ESPON, 2005, project 1.1.4). For the purposes of the present study the main influences are rooted in the 19th century onwards. This was the period of the development of the largest colonial empires, which has set the foundations for much of the migration in the 20th and 21st centuries. The 19th century was characterised by the siginificant emigrant flux from many countries of Europe to the United States, Canada and Australia as well as, to a lesser extent, Brazil, Argentina, New Zealand and South Africa. However this tendency changed, and during the second half of the 20th century, Europe became a hosting region, largely as a legacy of the by then dismantled colonial empires and the aftermath of the Second World War. An anomaly to this trend was the flow of refugees as a result of the Balkan wars that took place in the 1990s, especially that in Bosnia and Herzegovina, and the reverse flows since 1995 as people returned home (Kröhnert et al., 2008).

\subsection{Phases of migration}

The period from 1950 to 1975 was characterised by important intra-European migratory movements between the poor peripheral countries and the rich central countries (France, Germany, and UK) due to the economic push and pull factors and the needs of the labour market. The main direction of flow was from Southern (Mediterranean) to North-Western European countries, especially from Portugal, Turkey, Cyprus and southern Italy but also movements from Ireland to the UK and Finland to Sweden. There were weak movements between Eastern and Western countries mainly because of the barrier formed by the Iron Curtain (ESPON, 2005, project 1.1.4).

During the 1960s and 1970s the extra-European flows started to exceed the migrations from Southern to Northern Europe. This can be explained using the push-pull model where poor people in former colonial countries such as India, Pakistan, sub-Saharan Africa, Brazil and the Caribbean were encouraged to migrate to former imperial powers such as the UK, France, Portugal and the Netherlands in order to fill the labour market for un- or low-skilled workers. These migrants settled in places where certain industries could be found, such as cotton mills and the garment industry for people from the Indian sub-continent in the UK. These locations were later to form important magnets exerting a strong pull for later waves of immigrants from these countries.

From 1975 to 1990 the extra-European flows into Europe decreased. In part this was probably because immigration became more difficult or illegal, and the official numbers decreased while unofficial, illegal immigration increased. During this period the expansion of the EU and the money flowing into the poorer economies started to allow them to develop and to reduce the influence of the push factors of poverty and unemployment, though this process was not to take full effect until the later 1990s.

During the 1990s there was an increase in immigration. Although legislation became more restrictive, extra-European immigration increased as existing immigrants brought over their family dependents to live with them. In terms of intra-European movements, the economic imbalances between areas significantly decreased and living conditions became more uniform among the EU countries. This started to have an effect of increasing the demand for labour in the newly growing economies such as Ireland which started to become a net in-migration country instead of a net out-migration source.

The beginning of the 1990s saw the collapse of the so-called Eastern bloc and the USSR which initially became translated into large-scale flows from Eastern to Western European countries as borders opened. However, this tendency decreased after 1995 as controls came into force in many countries. During the 1990s metropolitan areas were the most favoured spaces for immigrants. 
This has been a feature of many groups, partly because the urban areas saw the most demand for jobs and partly because immigrants saw a move to another country and an urban lifestyle away from a poor rural village as a social and economic improvement.

According to (Boswell, 2005), after 1973-74, Western Europe followed the same tendency as the rest of the world. As a result of the oil crisis Western Europe as a whole decreased its rate of migrant recruitment, but immigration flows continued in the form of family unification, refugee flows and some labour migration (Castles, 2000). Subsequently, in the 1980s and 1990s migration levels increased once more as economic growth resumed, reaching particularly high levels (Boswell, 2005; Castles, 2000). The western (Austria, France, Germany, the Netherlands, Switzerland, UK) and Nordic European countries are examples of this trend. In 2001 the average net rate of immigration was 3.0 per 1,000 inhabitants (OCDE 2004 cited in Boswell, 2005) and the OCDE described the main source country-receiving country patterns as: "Moroccans in Belgium; Iraqis and Afghanis in Denmark; Russians in Finland; Moroccans and Algerians in France; Poles and Turks in Germany; Romanians and Ukrainians in Hungary; Albanians, Romanians and Moroccans in Italy; Angolans and Cape Verde nationals in Portugal; Iraqis in Sweden; and Indians in the UK" (Boswell, 2005, p. 3).

The European Union has been responsible for trying to unify the member states' immigration policies, by elaborating policies to regulate the movements of legal migrants and also of refugees. While, on the one hand, European citizens are increasingly free to circulate, to live and work in other European Union member countries, on the other hand national policies are becoming increasingly restrictive regarding non-European Union migrants. "Fortress Europe" is the term that reflects the European policy of keeping non-European Union residents outside its frontiers (Bolesta, 2004).

Statistics from 2007 (Eurostat, 2007, ch. 1) reveal that the population of the EU-25 grew from 376 million people in 1960 to 460 million people in 2005, migration being one of the main reasons for this increment. Net annual in-migration to the EU-25 increased from 590,000 persons per year in 1994 to 1.85 million by 2004. Figure 2 shows the net migration, annual average growth, by NUTS 2 regions, 1 January 2000 to 1 January 2006 in statistical maps from 2008 by Eurostat (GISCO, 2009). There are clear patterns here of the source and receiving regions from within Europe, although there are also movements into and out of Europe too. These data are clearly out of date now but there is nothing better at present, illustrating one of the problems in understanding migration effects - poor statistics.

Living Reviews in Landscape Research

http://www. livingreviews.org/lrlr-2010-2 


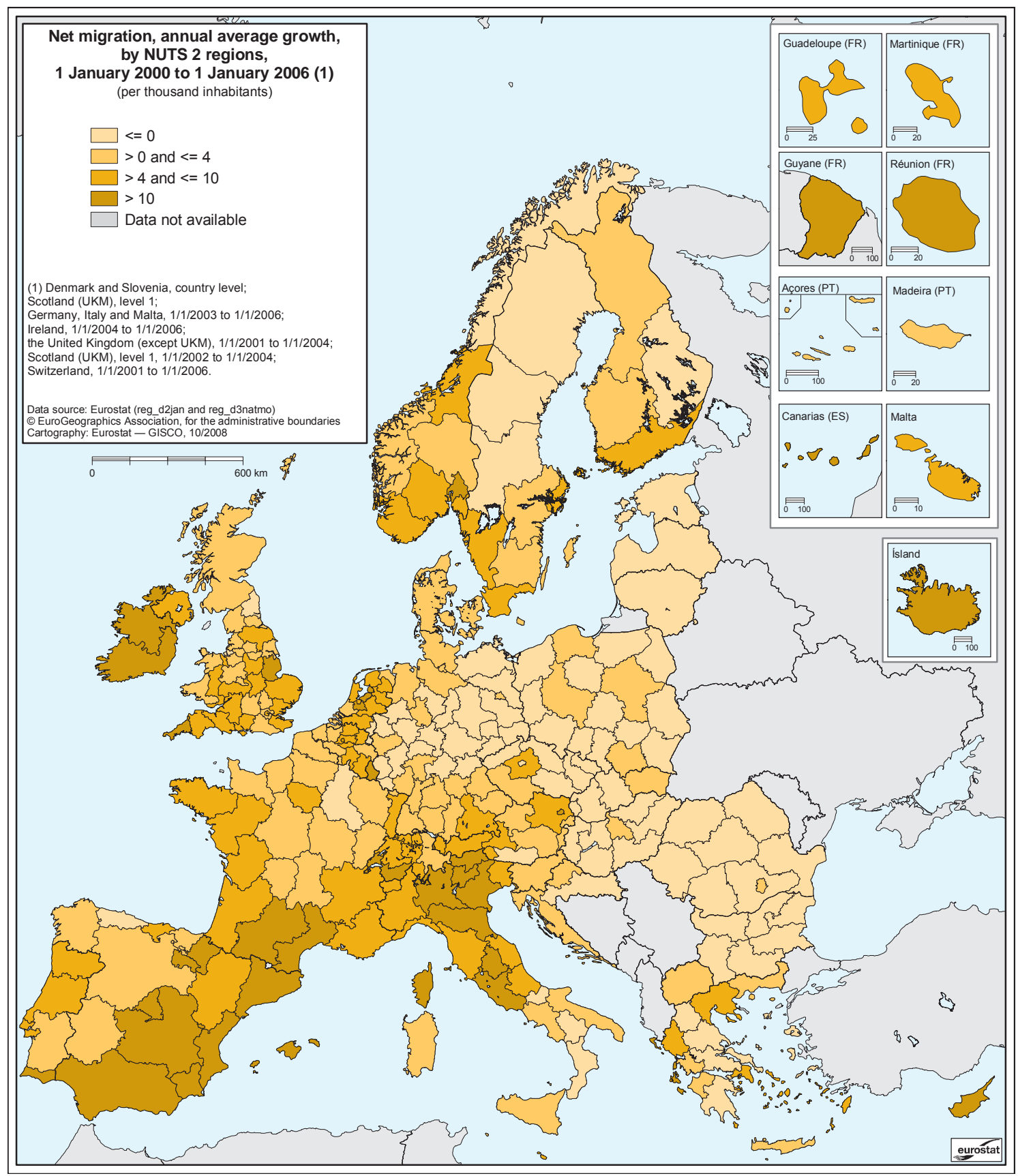

Figure 2: Map of European net migration between 2000 and 2006, encompassing the expansion of the EU in 2004 (Source: GISCO, 2009). 


\section{Types of migration}

Migration processes are not homogeneous, and different kinds of migration must be considered in the study of this phenomenon, especially when linking migration to land use change. As noted above in the explanation of the model, people migrate for a range of different reasons, but over the latter half of the 20th century, it became possible to identify three main types of international migration: labour and temporary migrations, including illegal migration, forced migration (refugee movements) and international retirement migration (IRM). There is also internal migration, most commonly from rural areas to urban centres but also a trend in some places for counter-urbanisation. These will be examined in turn.

\subsection{Labour migration in the EU}

Labour migration represents the movement of individuals from one country to another with the purpose of seeking work or responding to recruitment drives in another country. However, in labour migration it is possible to identify two types of migrants: highly skilled labour and unskilled low wage labour (including illegal or forced immigrants).

\subsubsection{Highly skilled labour migration}

This represents only a small percentage of migration (Peixoto, 2001) and it is the type of migration most demanded by the host countries who develop special types of incentives to attract highly skilled labour, often in specific categories, such as doctors and nurses (Castles, 2005). The attraction of highly skilled labour lies in the ability of the host country to accumulate human capital with no education or training costs (Figueiredo, 2005). However the loss of skilled labour, a phenomenon known as the "brain drain", can have severe consequences for the sending countries, which lose human capital and all the money invested in the education and training of the people who leave. Nevertheless, it can be seen as an attractive solution for solving problems of labour shortage and a way to increase economic production (Kubursi, 2006). Since the 1980s, the USA, Canada and Australia have had specific policies to attract skilled labour in particular categories, using a points system to score applicants who wish to emigrate there. This policy has been followed, more recently, by some European countries and parts of Asia (Castles, 2005). Highly skilled labour tends to comprise young to early middle-aged people who are from specific sectors, for example medicine or computer programming. Many people stay in the country they migrate to and then raise families and assimilate themselves into the population, retaining a high level of educational attainment in their offspring.

\subsubsection{Unskilled low wage labour and temporary migration}

After 1945 unskilled low-wage labour was the main type of migration which played a very important role in the economic reconstruction of the industrialised countries. Not all of this immigration is legal and some countries, such as the USA, have been very attractive to illegal migrants, especially from Mexico and other Latin American countries, willing to work in the "black economy". In 1988, Sassen, in her approach to the global cities, referred to the dual economy which uses these low skilled labourers as a primary source for the low wage jobs (in industry, construction and domestic service) (Castles, 2005). This constitutes the largest percentage of economic migration and is the process that attracts more attention from the media and social organisations (Kubursi, 2006). Unskilled low wage labour is usually also linked to illegal migrants who clandestinely enter the host country. Such people are the most vulnerable to unjust exploitation and human rights violations, because they have an illegal status (Kubursi, 2006). If they remain they frequently end

Living Reviews in Landscape Research

http://www. livingreviews.org/lrlr-2010-2 
up staying in deprived areas and joining a community of deprived people and are unable to climb out of poverty without help.

When the Central and Eastern European countries joined the EU in 2004, large-scale labour migration from these countries to the west started, especially to countries such as the UK and Ireland, which did not impose any interim immigration controls. The labour market in the stillgrowing economies (until the financial crisis of 2008 and the subsequent recession) was and is primarily in three sectors: agriculture (picking and processing agricultural and horticultural products), the hospitality industry (hotels and restaurants) and construction. Many of these people are temporary migrants - possibly seasonal and also for short periods until they have amassed enough money to start a business back home, for example. These migrants are also usually young but may include middle-aged people who may bring their dependents with them. Temporary migrants may be well-educated but unable to transfer their skills to the host country owing to the need for certain certificates for professions, for example, where the host country does not recognise their qualifications.

\subsection{Forced migration}

Forced migration includes not only refugees ${ }^{2}$ and asylum seekers fleeing war or political repression but also people displaced from their homes by projects such as dams or roads or as a result of certain natural disasters (Castles, 2003, 2005). Castles (2003) has also referred to another mode of forced migration, the trafficking of people, with special emphasis on women and children destined for the sex industry.

While some countries may be favoured destinations for such migration - asylum seekers to Britain have been an issue in recent years - other countries which do not otherwise feature as places receiving large numbers of labour migration may in fact welcome asylum seekers - Scandinavian countries, for example. The educational level of many refugees, especially asylum seekers may be quite high (their exile may result from them being politically active students for example) or, in the case of people displaced by civil war, it may be very low. Some asylum seekers return to their native country if the circumstances there improve (e.g., Iraqis returning after the fall of Saddam Hussein). Many assimilate into the local ethnic communities and become part of the multi-cultural society, often having a relatively low socio-economic status.

\subsection{International retirement migration (IRM)}

International retirement migration is a phenomenon of the northern countries such as Germany, the UK and the Nordic countries, characterised by the residential mobility of retired people who have the economic power to buy properties abroad (Rodríguez et al., 1998). Retirement is the main "push factor" to initiate this migration process (King et al., 1998). As a "pull factor" the pleasant climate characterised by warmer temperatures, the landscape, a quality lifestyle associated with a healthier and slower pace of life, and also the availability of information about the countries as well as previous holiday experiences are all elements that attract immigrants to southern European countries (Rodríguez et al., 1998; King et al., 1998; Lardiés Bosque and Castro Romero, 2002; Petrov and Lavalle, 2006).

\footnotetext{
2 According to the Geneva Convention on refugees, "refugee" is defined: "As a result of events occurring before 1 January 1951 and owing to well-founded fear of being persecuted for reasons of race, religion, nationality, membership of a particular social group or political opinion, is outside the country of his nationality and is unable, or owing to such fear, is unwilling to avail himself of the protection of that country" (UN, 1950). Some ratification were made to this convention, and in 1966 the refugee status was changed and expanded to every one who was being persecuted, by omitting the words "As a result of events occurring before 1 January 1951 and..." and "...as a result of such events" (UN, 1966)
} 
The major impact of these immigrants in the host countries is the pressure on urbanisation and the mass construction of housing in coastal and rural areas (Rodríguez et al., 1998; Petrov and Lavalle, 2006). According to the EEA (2006) the coastal zones of Portugal and Spain, along with Ireland, had the highest rates of urbanisation (20-35\%). In Spain retired immigrants settle in "urbanizaciones" (residential estates) (King et al., 1998) and the construction of these developments has a large expression in rural towns and villages on the Costa del Sol (Rodríguez et al., 1998). In Portugal, the Algarve is the most popular area for retirement. In this area, also due to the high levels of tourism, there is an increase of infrastructure construction and recreation. Golf, as one of the main attractions, has a direct impact on the "modification of dune soils, loss of natural vegetation, disturbance of sensitive wildlife and extra demand on limited water resources."(Petrov and Lavalle, 2006, p. 15). Retired immigrants tend to reconstruct semi-derelict farmhouses, live in villas in the rural areas adjacent to the coastal strip or settle in new urban development (King et al., 1998). According to King et al. (1998) retired immigrants in Italy, settle in rural areas in Tuscany - in "farmhouses" - but they also present a tendency for urban settlements in major cities such as Florence and Lucca.

There are migrations which are similar but not strictly associated with retirement since they involve people in mid- or late-career leaving their jobs and moving to rural areas in other countries, such as British people to rural France. They may tele-work or set up businesses but in essence they are looking for the same lifestyle as the retirees - that is, a less-stressful life, a better quality of life and perhaps the chance to live more cheaply on the same income.

\subsection{Internal migration}

This type of migration occurs inside a particular country, and between regions, especially from economically poor areas and rural parts to major cities. The effects during the 1990s can be explained by the social and economic disadvantages of living in some areas. This trend, which had occurred in western Europe for centuries, had been more-or-less arrested in the Eastern bloc due to social controls but once the socialist system collapsed along with the economies, large scale migration occurred which, with the incorporation of many of these countries into the EU became transformed into international labour migration. The patterns of internal migration can be quite complex and have profound effects on land use as will become clear.

In France, for instance, there is a north to south movement. However, in the old industrial areas of the north there is also out-migration, but in this case to the Paris region, while the inhabitants of the latter tend to move south, attracted by the good image of quality of life and a healthy economic dynamism associated with cities such as Toulouse and Montpellier (Kröhnert et al., 2008).

The Scandinavian countries have seen movements from peripheral regions and industrial areas to metropolitan areas. This tendency has been reinforced during the 1990s. In Sweden and Finland, for example, there has been large-scale rural depopulation of more remote areas and the main cities have expanded, so that increasing proportions of the population live in cities (Kröhnert et al., 2008). This has resulted in some places with largely emptied villages and the loss of rural services. These areas now tend to be dominated by, for example, industrial forestry.

In the former Eastern Europe (now referred to as the central and eastern European countries or CEE) in the period since the collapse of the Soviet bloc, large-scale movements from rural and old industrial areas to metropolitan regions have taken place. This has been followed by outmigration to other European countries. The rural areas contain a lot of abandoned land and may be dominated by old people who have been left behind. There is a tendency for young people to leave to seek education as well as work but not to return to rural areas. However, inside the metropolitan areas there is a tendency for suburbanisation away from Soviet or socialist era housing estates dominated by large panel buildings to single family houses in the suburbs, contributing to urban sprawl.

Living Reviews in Landscape Research

http://www. livingreviews.org/lrlr-2010-2 
Counter-urbanisation is another type of internal migration and represents the movement of people from urban to rural areas. In England, contradicting the world's tendency, this movement is increasing and has been observed since the 1980s (Hardill et al., 2004). This phenomenon is characterised mainly by the in-migration of older couples and "relatively well-off families", which balance the rates of younger groups moving into cities, and can be explained by four drivers: "commuting patterns; work-driven migration; pre-retirement (movement to rural areas with job but with the intention of retiring in that place); retirement related moves" (Lowe and Stephenson, 2003, p. 2).

The number of older people living in rural areas is also increasing, being nearly $28 \%$ and it continuing to increase (Lowe and Stephenson, 2003). In the UK, the 'retirement areas' - places that most attract 60-74 year olds - are primarily seaside towns and rural-coastal areas (Champion, 2004, p. 29). Hardill et al. (2004) identify the aim of many people of "re-establishing some quality to life", after working hard to build up some financial stability, as impulses for retirement migration to rural areas. In this case, the financial resources work as a "push factor" and the desire for a better quality of life a "pull factor". Also in Ireland, the aim of living in rural areas, near to nature and with a better quality of life, as well as the wish of living in a single family house (EEA, 2006) can also be considered to be "pull factors". In addition, population growth in cities, high property prices in the city centre and the small size of houses, along with a deficient transportation system work as "push factors" for urban-rural migration.

In some CEE countries there is a small trend for counter-urbanisation. For example, in Estonia, Kontuly and Tammaru (2006) have noted the movement of older people to rural areas, returning to the places of their birth after being forced to live in cities or towns during their working life. In these places the family may own a rural property which was reinstated to them after the end of the Soviet system. 


\section{Characteristics of immigrants in urban areas}

The composition, size and characteristics of Europe's migrant population is largely unknown and difficult to describe, mainly due to the fact that migrants are defined differently in different countries; the data collected also varies (Münz and Straubhaar, 2006).

According to Vasileva (2009) in the beginning of 2008, 30.8 million non-nationals were living in the EU-27 Member States, constituting $6.2 \%$ of the total European population. Nearly one third (11.3 millions) were from one of the EU-27 Members states, while nearly $20 \%$ were from a non-European country: $15.2 \%$ from Africa followed by Asia (12\%) and America (10.3\%). In terms of demographic characteristics, the ESPON project 1.1.4 (2005) characterised the majority $(56 \%)$ of the immigrants as being between 25 and 55 years old. On average, immigrants tend to be younger than the host population (Kröhnert et al., 2008) and the oldest immigrant population was mainly from Southern Europe, as well as migrants from north-western, living in another EU country (presumably retirement migrants) (ESPON, 2005, project 1.1.4). In terms of gender, in 2000, more than $52 \%$ of immigrants were women (Gallotti, 2009). Nonetheless this representation is not linear since, as pointed out by the ESPON project 1.1.4 (2005), women were over-represented among immigrants from the Balkans, Central and Eastern Europe and from Latin America, as well as immigrants from north-western Europe. On the other hand, immigrants from Turkey, North Africa, Middle East and sub-Saharan Africa were mainly men.

Most of the international immigrants settle down in urban areas due to the economic, cultural and social opportunities that large cities can offer (Malgesini, 2006). Along with these opportunities, the available market for non-skilled jobs (Fonseca, 2001; Malheiros, 2002; Malheiros and Vala, 2004), social networks (use of human capital inherent in the ethnic networks, relatives and friends in the host country, information) (Arapoglou, 2006; Hårsman, 2006; Malgesini, 2006; Malheiros, 2002; Malheiros and Vala, 2004), family reunion (Deurloo and Musterd, 1998), labour recruitment policy and historical and cultural links (colonial past and share of same language) (Deurloo and Musterd, 1998; Malheiros, 2002; Malheiros and Vala, 2004) result in "pull factors" to immigrants.

The settlement of immigrants and the demographic growth of their descendants has a social impact on cities (Malheiros and Vala, 2004) contributing, in some cases, to a high degree of urbanisation (Malgesini, 2006) Spatial segregation in some cases is a consequence of the presence of immigrants in cities (Gaspar, 2001). Ethnic segregation in Europe is related to the recent waves of international immigration characterised by labour immigrants, immigrants from the former European colonies and refugees, (Fortuijn et al., 1998). In the American literature, under the influence of the Chicago School, it is possible to find references to the idea of "ghetto", representing an idea of high levels of urban segregation and poverty (Fortuijn et al., 1998). In the European context "few ghettos can be found", mainly due to the recent experience of segregation (Fortuijn et al., 1998, p. 367). Nevertheless, in a different scale from the American context, "segregation also shapes cities" (Kaplan and Woodhouse, 2004, p. 580). Segregation is seen has a failure of assimilation of the ethnic minorities and most of the countries aim to reduce ethnic residential division. (Malheiros, 2002) has also identified two different scenarios in Europe regarding the settlement of immigrants and segregation patterns: the southern European cities are characterised by low levels of ethnic and social segregation, while the Northern European cities present higher levels of segregation. He considers the differences in immigration (different periods of migration, the multiplicity of immigrants and the high percentage of non-legal immigrants involved in informal activities in the southern European Countries) and the divergence of urban and house policies ("late industrialisation and suburbanisation", lack of public housing in the southern European Countries) (Malheiros and Vala, 2004, p. 1067) as key elements for these differences. As an example of this scenario, in Greece, Albanian immigrants experience a low index of segregation in Athens, mainly through their capacity to live among the Greek population and in different areas of the city (Arapoglou, 2006). However, other immigrants from central and eastern Europe, and also from Asian and

Living Reviews in Landscape Research

http://www. livingreviews . org/lrlr-2010-2 
African countries have their own communities and tend to live closer together and somewhat more segregated, and examples can be found in the literature. The civil unrest which occurred in the Parisian suburbs (banlieus) in 2005 could be seen as one example of the consequences of a certain degree of ethnic segregation. In his studies of these "sensitive neighbourhoods" in Paris (Shon, 2010, p. 1603) concluded that the more disadvantaged the neighbourhood is, the harder it is for its residents to move into a less deprived area. As an example, he pointed out the fact that Africans faced more challenges to move out, being instead more prone to move into the least-advantaged neighbourhoods. In Italy, Mingione (2009) refers to examples of social tension between the resident population and the foreigner communities (Chinese and Romanian) in Milan, as an example of ethno-spatial conflicts and apprehension among ethnic communities. (Arapoglou and Sayas, 2009) identified a certain degree of spatial segregation based on gender and employment, not only among female immigrants but also the resident population. According to these authors female domestic and unskilled service migrant workers tend to be located in city centre and suburban areas, while intra-movements of local residents are also present. 


\section{$6 \quad$ Predicted migration and resulting population changes}

The future migration map of Europe will depend on several factors including the changing balances between push and pull factors which may increase or decrease migration from different areas or in different directions and immigration controls to migration from outside the EU. The overall population of many European countries is expected to increase largely as a result of migration rather than through demographic growth (Eurostat, 2007, ch. 1). The pattern of migration is also affected by the composition of the migrants. Eurostat has produced some forecasts of net population increase and anticipated migration for the years 2004-2031. These help to evaluate the effects and to link these to land use change. However, there are drawbacks to these projections, not least because there is incomplete data at a European level and the resolution of the data varies considerably.

Figure 3 shows population relative change 2004-2031 at NUTS 2 (in general, although for France and the UK it is NUTS 1) while Figure 4 shows net international migration (cumulative change), by NUTS 2 regions, 2005-2030 but not for all countries due to a lack of data. This absence of data is a major problem, especially as the UK and France are major locations for migrants to move to while the Balkans and Baltic states are major sources of migrants. In addition these maps and the data underlying them do not capture or present the nature of the migration patterns in terms of flow. Thus the quality of these prognoses for planning or policy responses is questionable. The authors of this paper have tried to improve the understanding of flows by examining the literature sources reviewed above and from this to determine the anticipated main patterns of migration. The pattern for within Europe is shown in Figures 5 and 6 in terms of the main sources and receiving destinations and also the directions of flows between them (Figure 5 shows the primary flows and Figure 6 the secondary flows). The main flows from outside the EU are shown in Figure 7.

One of the characteristic features of the migration flows from outside the EU is the popularity of the countries which were the former colonial powers in the 18th to 20th centuries as potential receiving countries. This places particular pressures on the UK, France, the Netherlands, Spain and Portugal. The other feature is the continuing link between Germany and Turkey and the expected flows from the former Soviet Union, some of which are already fairly strong, such as that of Ukraine to Portugal.

These anticipated flows will present major challenges for many countries in assimilating migrants into society, with potential dangers of the development of more ghettos and urban areas dominated by certain ethnic groups probably living in rather deprived conditions and needing more and more social support, special education programmes owing to language problems and so on. The political implications should not be underestimated either. Social cohesion, national identity and perceptions about over-population are issues that are already being raised by politicians in many countries. In countries where fertility rates have been falling the more fertile migrant populations may affect the balance of ethnic composition in school classes in certain inner city locations, for example and there may also be perceptions that there is some kind of threat to the ethnic make-up of cities or countries which is also on the political agenda in some places.

At this point, we can return to the concept of 'environmental supportiveness' to make the point that a balance or fit in terms of the migration-landscape change relationship demands the analysis of multiple issues - those addressing migrants' motivations and reasons for migration, socio-cultural characteristics, political and economic factors making up the migration process, environmental and ecological impacts as well as legal procedures for each country.

Living Reviews in Landscape Research

http://www. livingreviews.org/lrlr-2010-2 


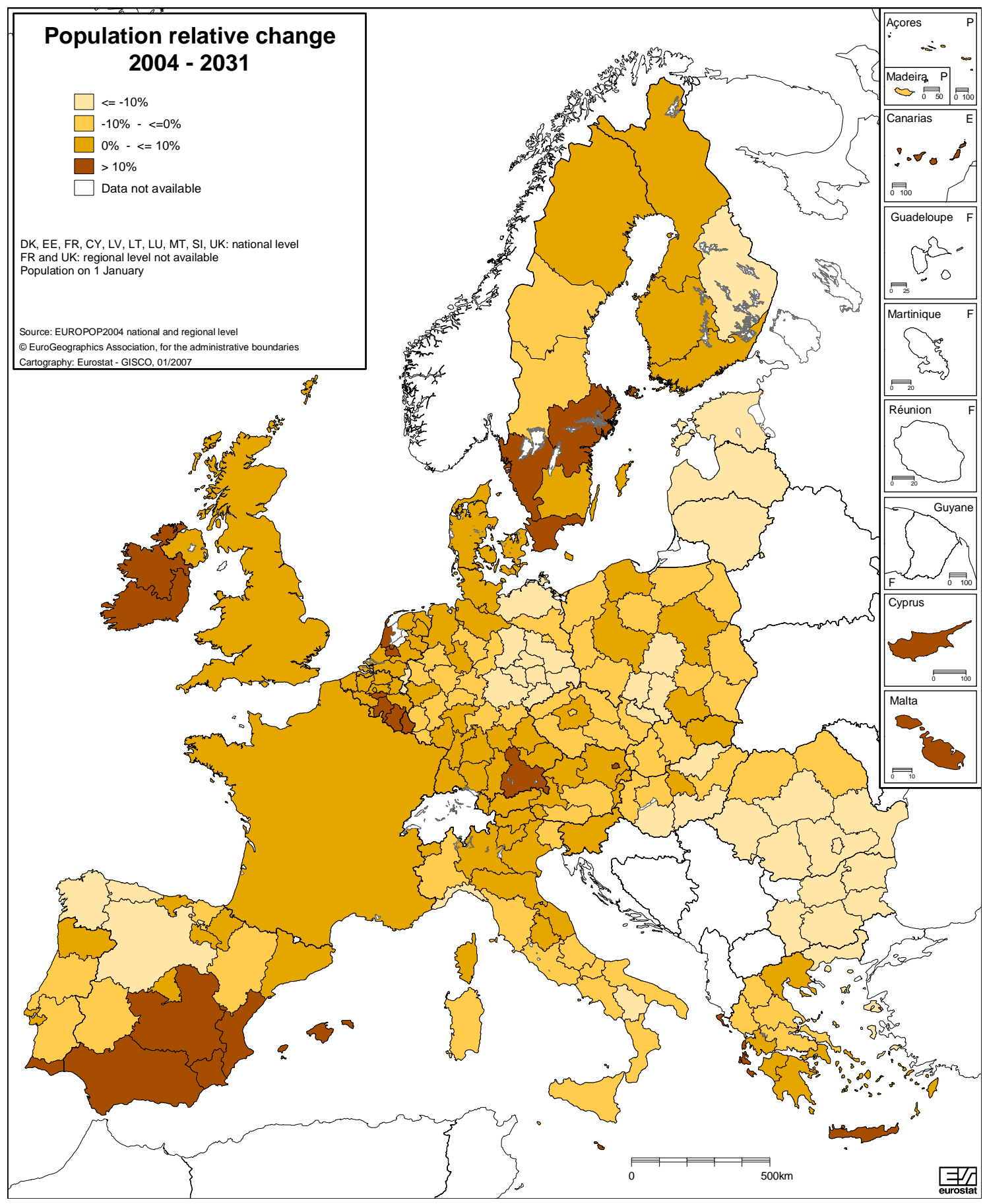

Figure 3: Map showing expected relative population change in the EU from 2004-2031. Note the gaps in data and also the varying spatial scales of resolution, especially in the UK and France compared with other countries (Source: GISCO, 2009). 


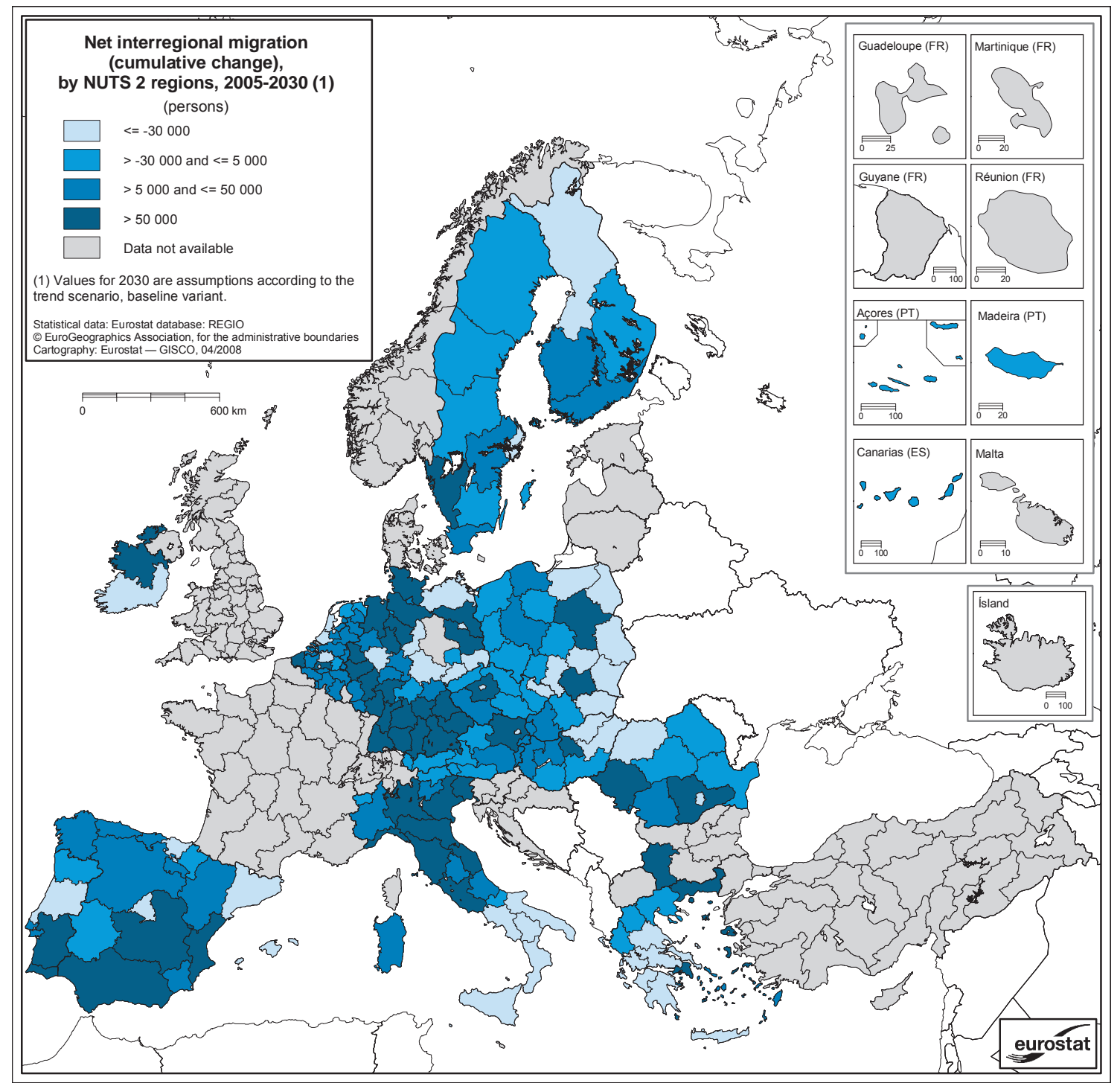

Figure 4: Map showing net projected cumulative changes in international migration for selected countries. Note the major gaps in data, representing some of the major source and destination countries for intraEuropean migration flows (Source: GISCO, 2009). 


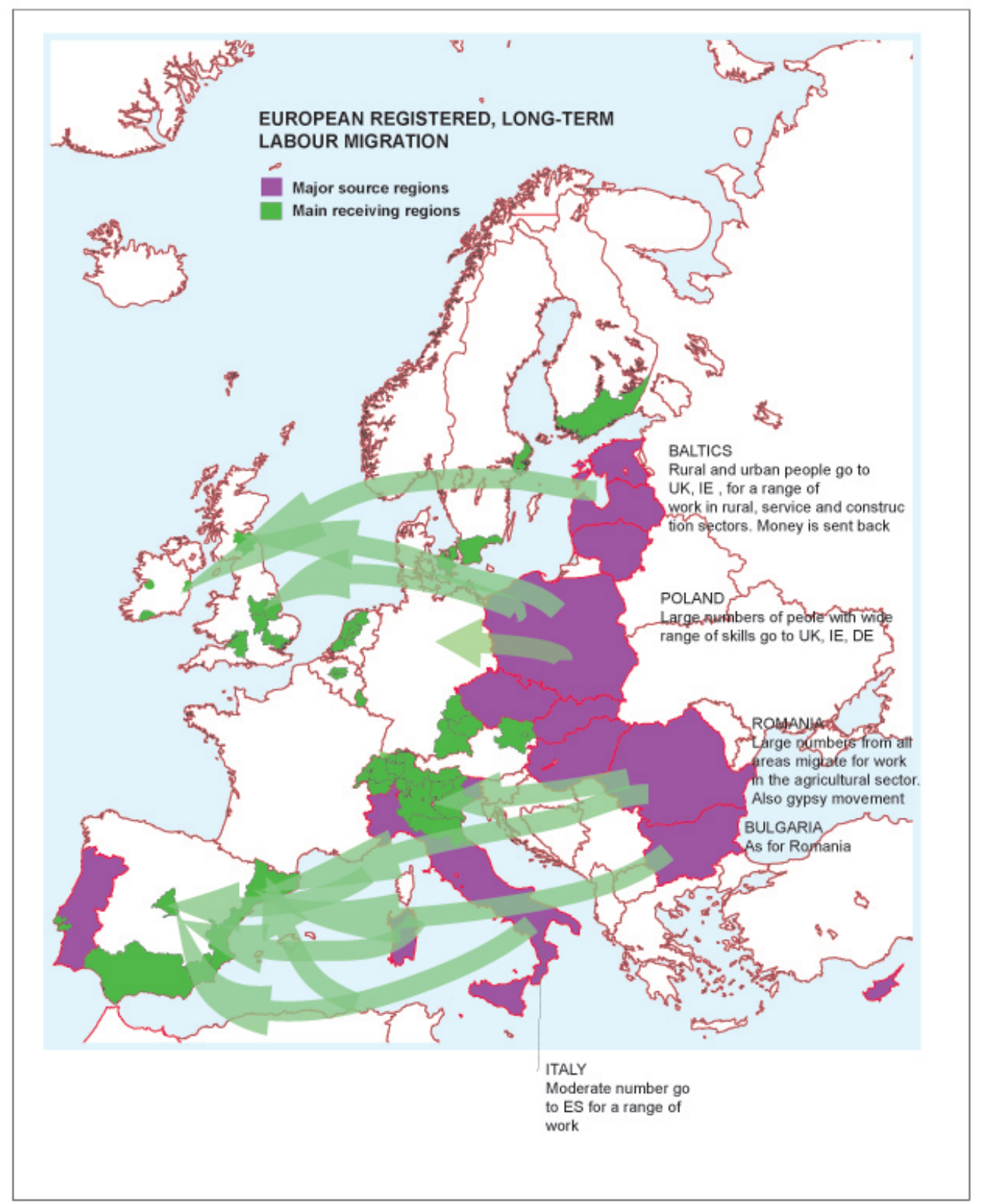

Figure 5: Map showing expected primary flow directions of EU migration, in relation to the main source and receiving locations, as derived from the literature reviewed in the paper (Source: OPENspace). 


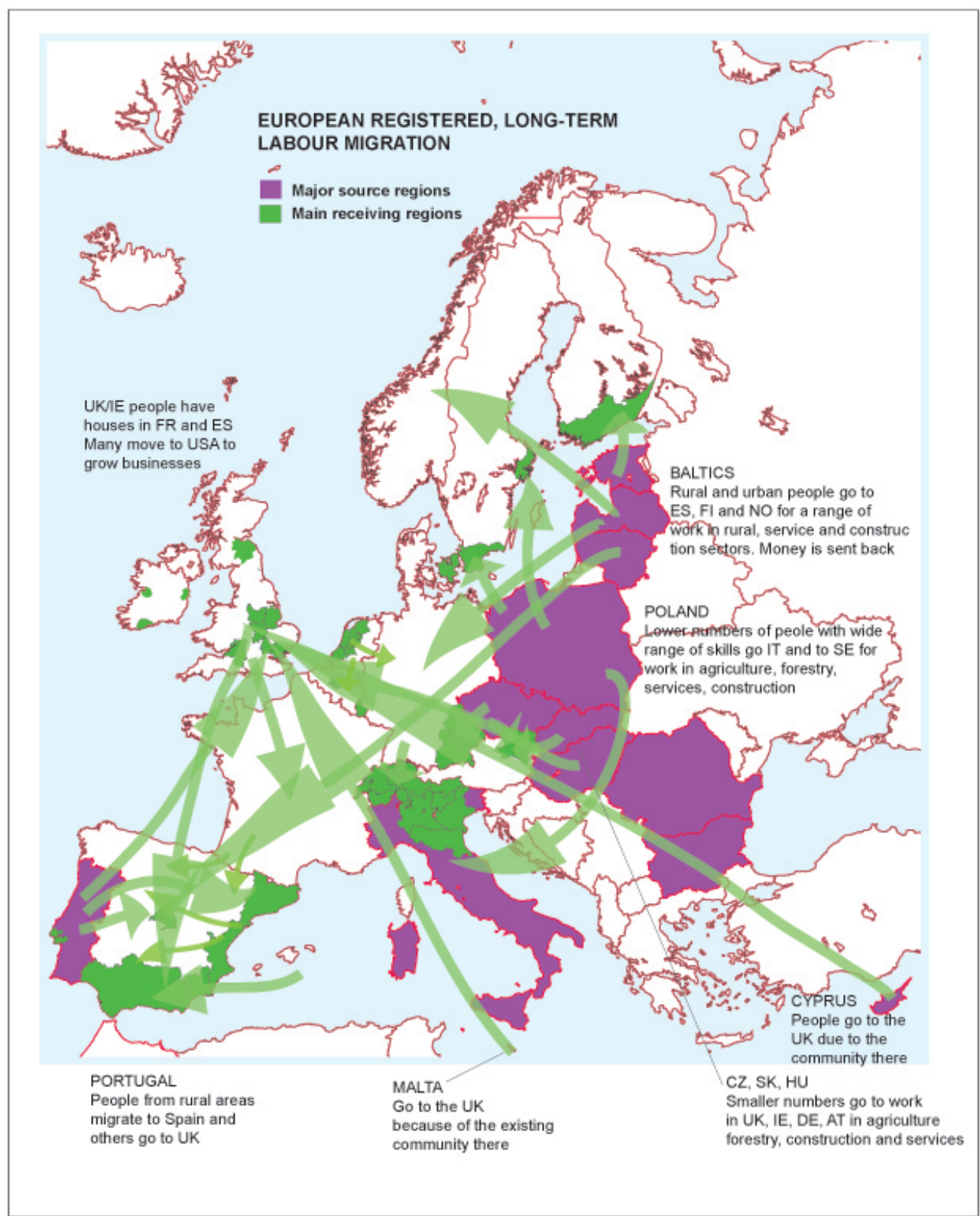

Figure 6: Map showing the expected secondary migration flows in the EU in relation to the main source and receiving locations, as derived from the literature reviewed in the paper. (Source: OPENspace). 


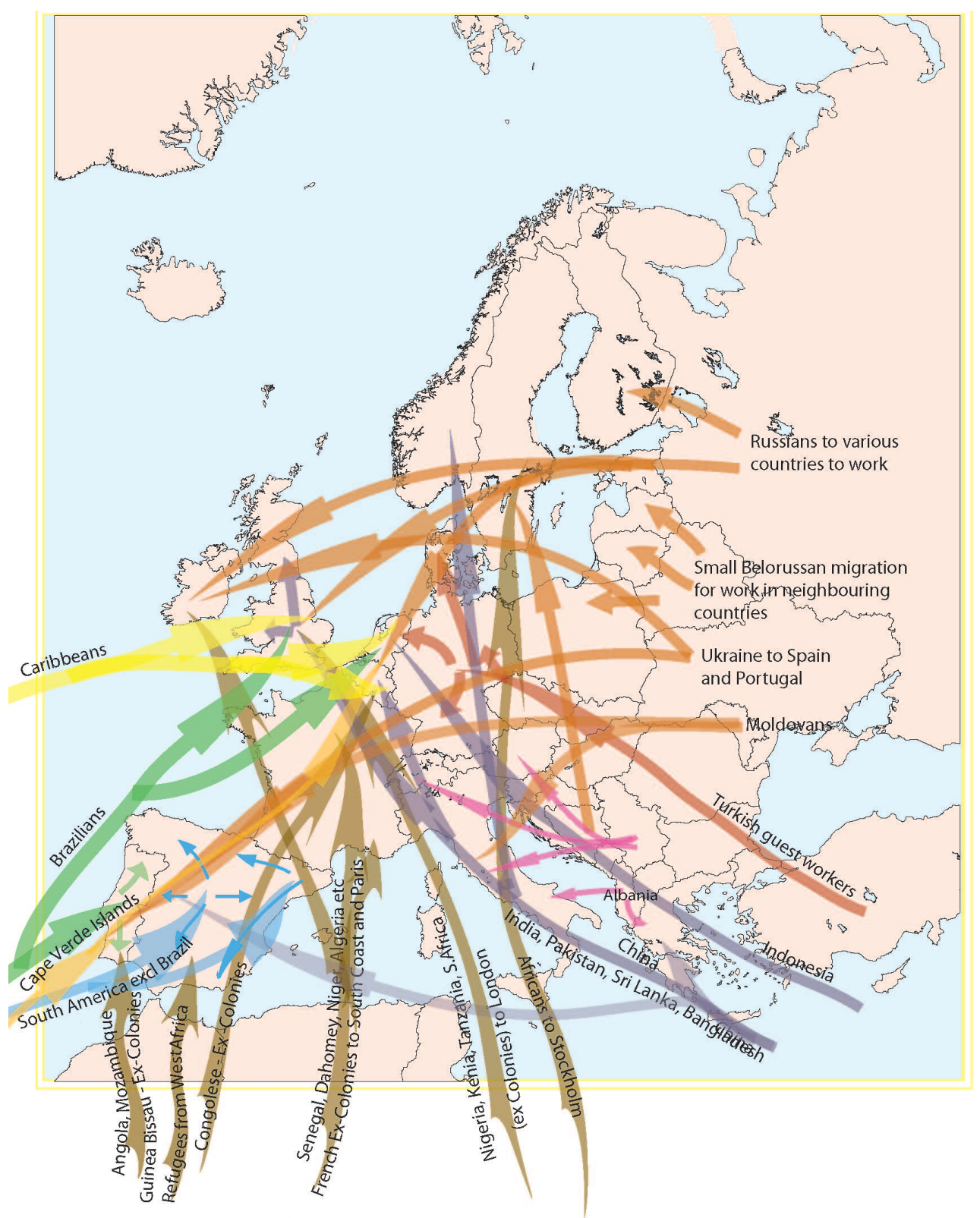

Figure 7: Map showing anticipated migration flows from outside the EU and their main destinations, as derived from the literature reviewed in the paper. (Source: OPENspace). 


\section{$7 \quad$ Land use change processes resulting from migration pres- sures}

This section starts a process of examining the implications of the review undertaken so far, converting the understanding of migration pressures into actual or potential land use changes. While the connection between migration and land use change is complex and difficult - the land use responds to the pressures caused by migration in different ways in different places - it is an important and, so far, little studied aspect with potentially major implications for European land use, environmental and social policies. The problem with calculating projections, for example, is the current lack of data. Therefore, until better, more comprehensive and spatially resolved data becomes available it is necessary to interpret the available data and trends from the data presented in the above review qualitatively. It is also necessary to be quite flexible in considering what is likely to happen in the future and how current trends are likely to evolve, because of the complexity of the combination of push and pull factors in any one migration category as well as the combination of categories which may affect a particular area, as noted in the literature review sections. Data exists and some predictions have been made which are available in the references cited earlier and in the sets of maps produced by Eurostat, at least for where data is available (it is not comprehensive for the EU and often omits the Balkans as noted above).

In order to determine what kinds of land use changes are likely, it is necessary to be able to see how migration flows work spatially, to see where migrants come from and where they go to as well as what kind of migrants and what they do when they arrive, where they are likely to live and so on. There are some clear patterns which can be categorised as geographical or as motivational but which are inextricably linked together and so cannot be considered separately.

The literature review above shows that certain countries are experiencing migration from rural areas to urban areas: Eastern European countries, Portugal and Nordic countries, for example; others are experiencing counter-urbanisation from urban to rural areas: the UK, France, Spain, Italy (not necessarily French people but also British, Dutch and German to rural France, Spain and Italy, for example). This leads to several trends: urban growth as a result of migrants moving to urban areas, where they often live in low-rent accommodation to start with and often cause an increase in multi-occupancy in residential areas and urban densification. This may not be very visible as a land use change when mapped but is nevertheless significant. The counter urbanisation leads to the so-called "gentrification" of the countryside in regions around cities, within the commuting zone. It also leads to the regeneration of rural areas in France, for example, where old houses are renovated and dying villages are repopulated.

Although the impact of immigrants in urban and peri-urban areas is more noticeable, in some countries, such as Greece, the countryside also benefits with the migration process through a replacement process. With the rural exodus of people from countryside to city, immigrants replace some of these emigrants and undertake the hard and difficult agricultural jobs abandoned by the original locals, allowing a change from extensive (such as wheat production) to intensive agriculture (Labrianidis and Sykas, 2009).

European labour migration is primarily from Eastern Europe to Western Europe, especially the UK and Ireland. The people often come from rural areas back home (where the rural depopulation is worst) to both rural and urban areas in the receiving countries. They generally live in low-rent areas, often in places where people from their country already live, frequently in inner cities as opposed to suburbs. This leads to denser populations and an increase in multi-occupancy but these people are there to earn money and they do not normally receive benefits or live in public housing. There is also a turnover of people, some staying for longer periods or becoming permanent residents, moving into better housing as they prosper, while others come seasonally. These latter come often for agricultural, horticultural or forestry work and as such they indirectly contribute to the intensification of agricultural areas such as the Netherlands, Eastern England and parts of

Living Reviews in Landscape Research

http://www. livingreviews.org/lrlr-2010-2 
Ireland.

Non-EU migration is from a range of countries and as a result of a range of push-pull factors, mainly economic or political (especially with asylum seekers). These people may also be invited to countries to fulfil labour shortages for key jobs (highly skilled migration). Invariably these people move into inner urban areas or peripheral public housing estates and first generation immigrants from developing countries frequently end up in deprived areas with low incomes. They may displace earlier generations or groups of immigrants who move into better places and so create a wave effect which results in pressure to develop housing in peri-urban areas. There are distinct patterns of migration, with many countries of origin being former colonial countries of the various European empires of the last 200 years, so that there are distinct ethnic groups concentrating on some countries but those which did not possess empires tend only to have a few immigrants, mainly asylum seekers or refugees (Scandinavian countries for example).

International retirement migration has very distinct patterns and one of the most obvious land use change effects as a result. The suburbanisation of rural areas in Spain and Portugal is a clear example of this.

Figure 5 and 7 above show the patterns of movement of migrants around and into Europe, showing where the main pressures are. The next section considers how this pressure can be converted into predicted land use change. 


\section{Projected effects of migration pressures on land use change at NUTSx}

The paper from now on looks at the analysis of the material presented in the review and attempts to interpret it into potential patterns of land use change. Firstly the findings from the review are converted into major patterns of migration flows and secondly these flows are converted into a model of projected land use change resolved to NUTSx. The calculation of this and the shift from NUTS 2 to NUTSx was carried out by examining the NUTSx maps and identifying which areas were primarily urban, primarily rural or a mix of the two and whether they were locations of out-, in- or no-net migration. From this the likely shift in land use was assessed. The literature also helped to identify specific trends in each country which could be ascribed to the relevant land use types (Kröhnert et al., 2008). This approach is recognised as being somewhat crude and is likely to be significantly revised if and when better and more comprehensive data becomes available. However, it is a first initial step at trying to relate data from a range of sources which do not explicitly discuss land use into implications for land use change.

The analysis process identified that there are several types of land use change currently taking place, sometimes with a number of sub-types occurring within each NUTSx region. These land use changes taken from the evidence of studies from various locations were then extrapolated into other similar areas. This basic interpretation would enable a certain degree of modelling within a region to be developed if so wished, as part of a future research project. Three case studies illustrate three aspects of land use change in response to migration in order to demonstrate that these responses actually occur.

The following Table 5 describes the land use change typology adopted here and Figure 8 presents the spatial pattern. Because Europe is still largely rural despite the scale of urbanisation the map seems to show more rural types than urban types. However, many rural NUTSx regions contain towns and other urban areas while the urban areas may appear as the core territory surrounded by a peri-urban ring. This depends on the way the NUTSx boundaries have been drawn so the degree of detail for urban and peri-urban regions varies from country to country. This is a drawback in the model, especially when peri-urban areas are a focus of land use change studies as in the PLUREL project but it is inevitable when the scale of resolution is NUTSx. 


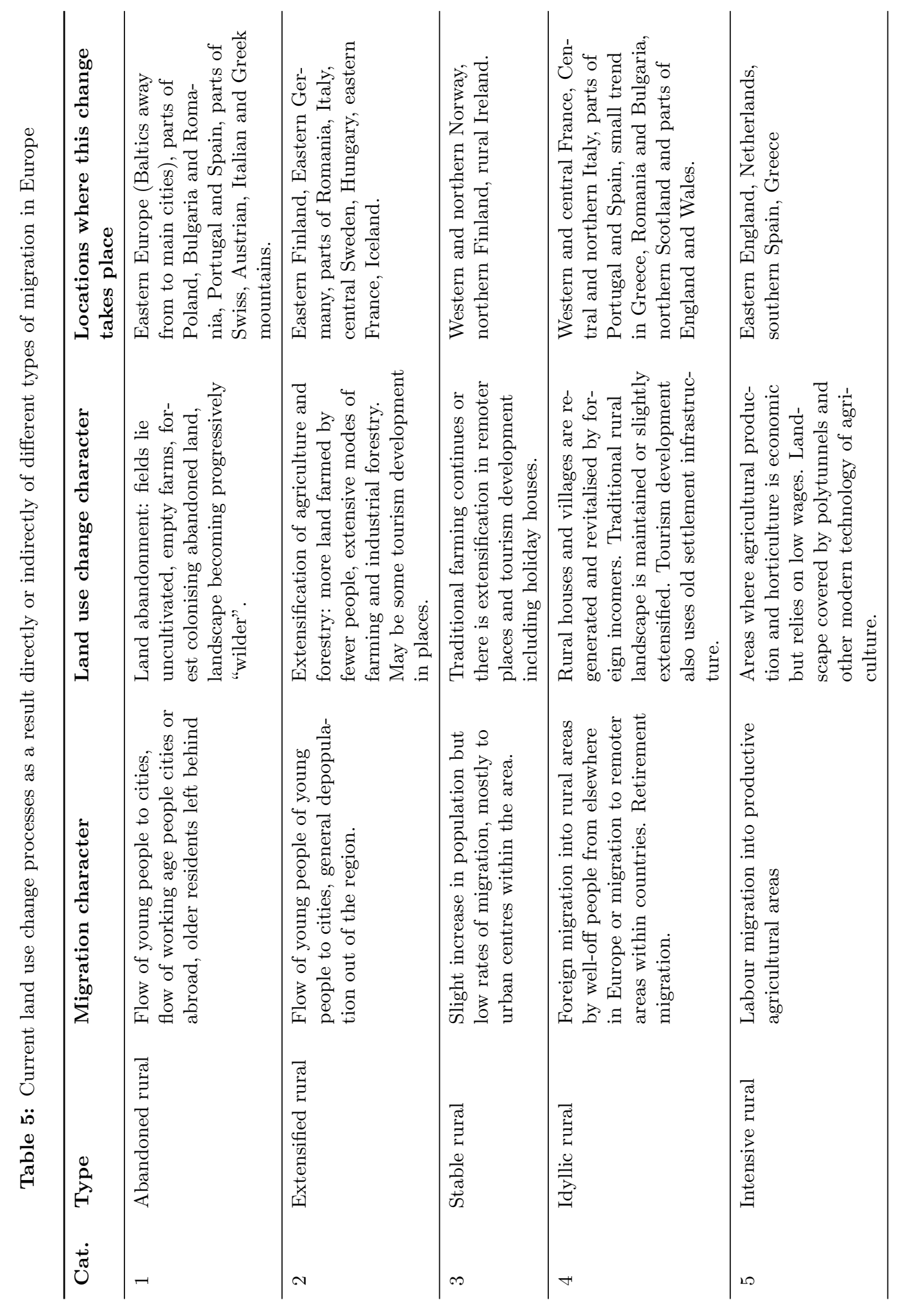




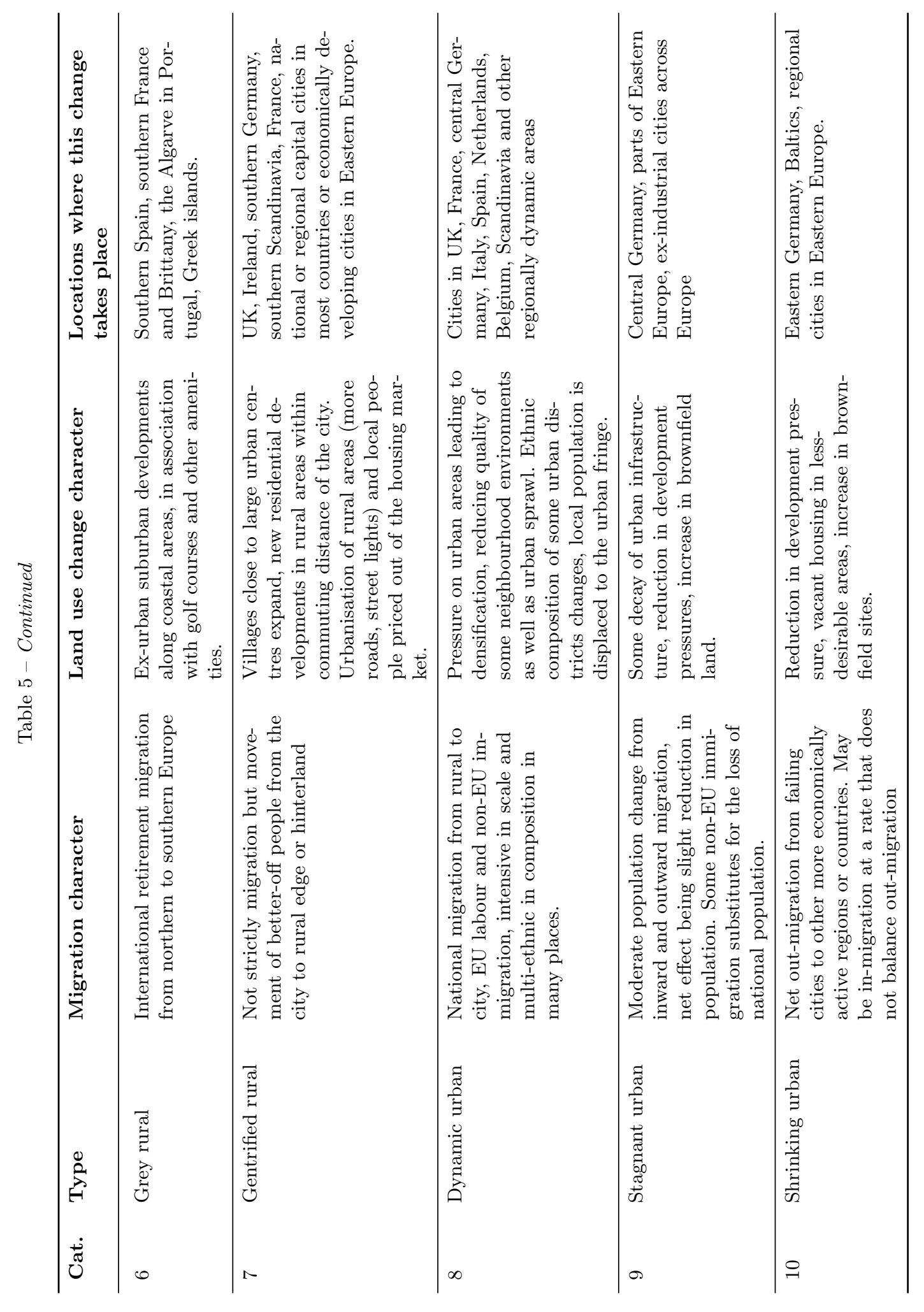




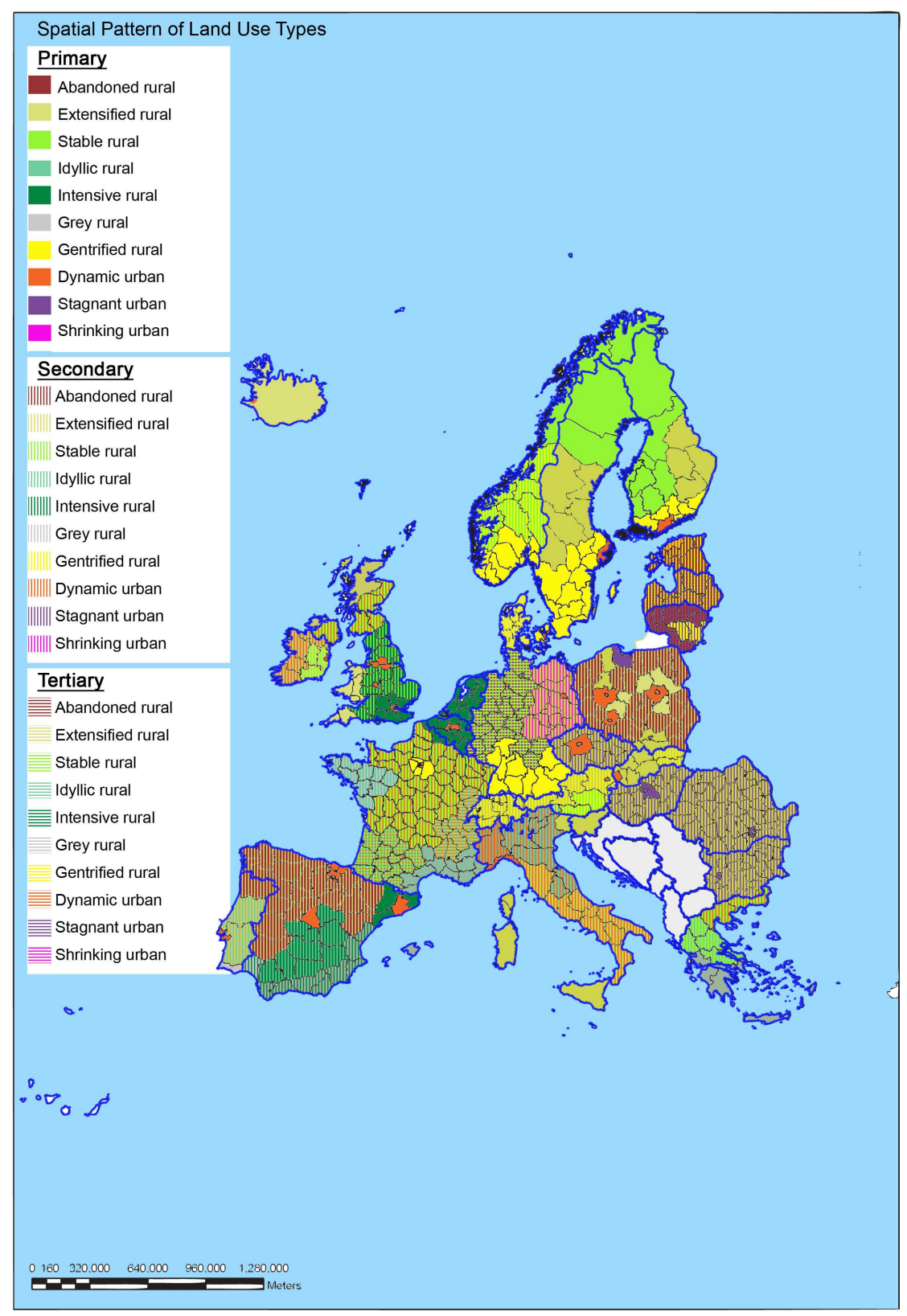

Figure 8: The spatial pattern of land use types according to the model arising from migration processes at NUTSx (Source: OPENspace). 
The following examples illustrate actual land use changes through different types of migration for three countries in Europe.

\subsection{Land abandonment in Latvia as a result of out-migration}

Following the collapse of communism in Eastern Europe and the Soviet Union, the rural areas became sources of large-scale out-migration, firstly to towns and cities and, more recently, abroad. The situation in many countries can be exemplified by the case of Latvia, which was part of the Soviet Union and since 2004 is part of the EU. During the Soviet era the countryside was extensively changed through the process of collectivisation, where private land was abolished, the fields were enlarged and often drained for large-scale machinery-based cultivation and the population were moved into blocks of flats in the village centres. People were more-or-less forced to live and work there. Once the system collapsed and Latvia became independent many social and economic forces which had been suppressed were released. The land was restored to the original owners or their descendents and the collective farm system was broken up, leaving a legacy of abandoned buildings and ill-maintained drainage systems. The social and economic hardships which developed from that time were the initial conditions for migration, firstly to the cities and latterly, with the accession of Latvia to the EU in 2004, migration abroad (Bell, 2009a).

The drivers of migration are as follows: the main push factor is the absence of jobs and low quality of life in rural areas as well as the dismantling of the collective farms system in the early 1990s (Bell et al., 2009a; Bell, 2009a; Bell et al., 2008). The pull factors include the opportunities for education and better paid jobs in urban areas, especially the capital, Riga and, since 2004, the prospects of employment abroad, especially in the UK and Ireland. The results of the depopulation include a marginalised and impoverished older population suffering social and economic isolation in more remote rural areas as well as large-scale land abandonment in part due to lower levels of land management by these older people as well as absentee owners who received their land at the restitution but who do not live there, resulting in natural re-afforestation of cultural landscapes and widespread presence of ruined buildings from Soviet and pre-Soviet times (Bell et al., 2009b; Bell, 2009b). Figure 9 shows a map of one rural municipality demonstrating the extent of abandoned land. Figures $10 \mathrm{a}-\mathrm{c}$ show abandoned land turning to forest, a Soviet-era ruin from a collective farm, and a collapsed old farmhouse.

\subsection{Suburbanisation of the rural coastal landscape in Spain as a result of international retirement migration}

In southern Spain an influx of retired people from Northern Europe to live there year round has occurred over the last 20 years. Amenity related migration, the category described here is sought by older people who are usually in good health and who have the social and financial resources to support their decision to move. This group of retirees target 'Sunbelt' areas, such as the Alicante region of Spain. It includes 'multiple movers' defined in the literature as including seasonal migrants; 'second home owners' or 'third-age long-stay tourists' (Williams et al., 1997). Britons are attracted to Spain by the combination of a high quality of life and a warm and sunny climate as well as low housing costs, although this has changed to some degree with housing price inflation and, very recently, with a change in the exchange rate devaluing the pound against the Euro.

The characteristics of retirees are that 1) they are highly culturally embedded within their British and Northern European perceptions of landscape and urban tradition; (2) they demand a hedonistic lifestyle focusing on natural amenity; and (3) leisure as well as age-specific requirements are central features of IRM, which can be related to demands on and expectations of the appearance of the urban landscape. The density of settlement is greatest within a $10 \mathrm{~km}$ zone

Living Reviews in Landscape Research

http://www . livingreviews . org/lrlr-2010-2 


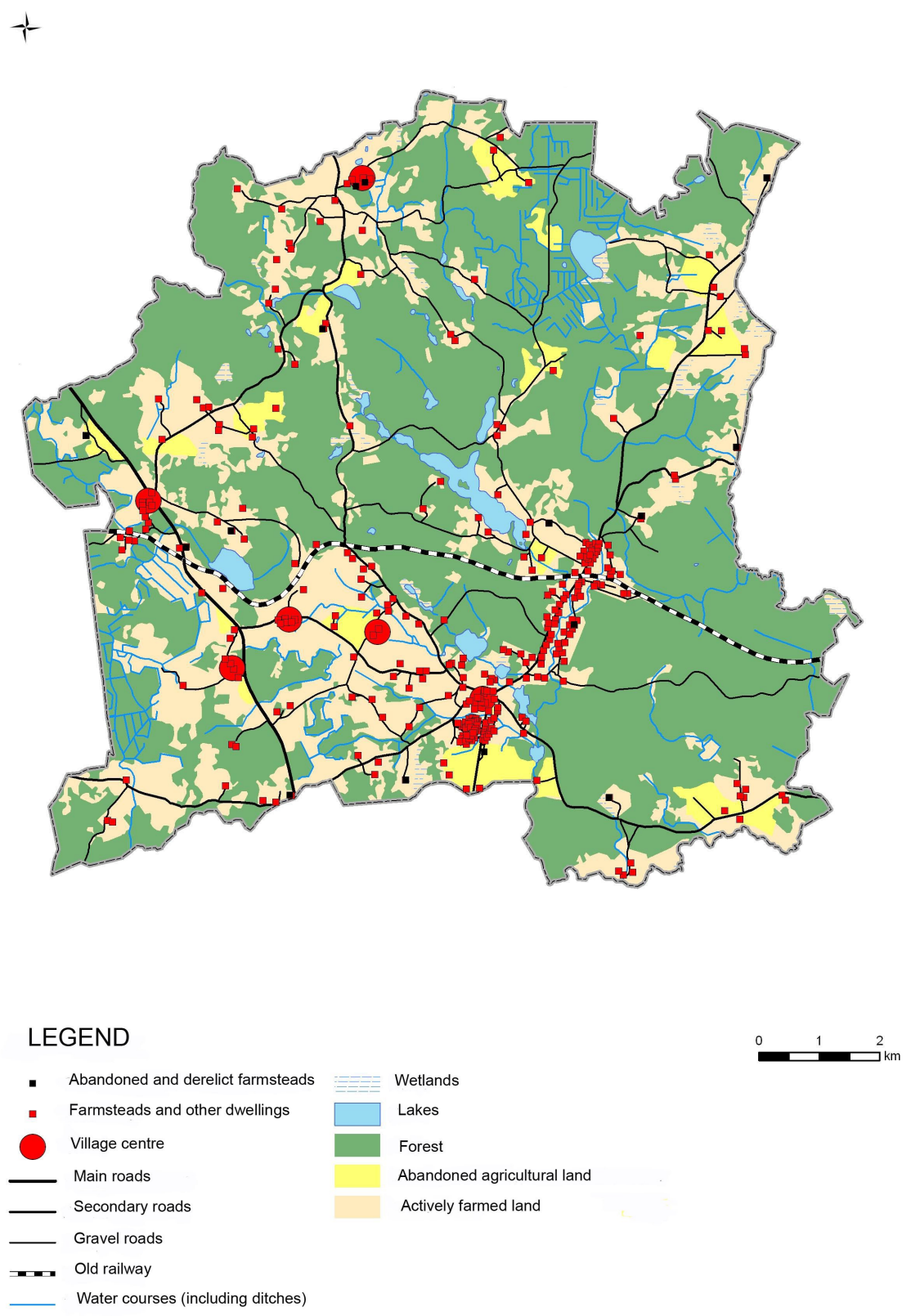

Figure 9: Map showing the land abandonment in Dzerbene pagast (rural municipality), Latvia (Source: Simon Bell). 

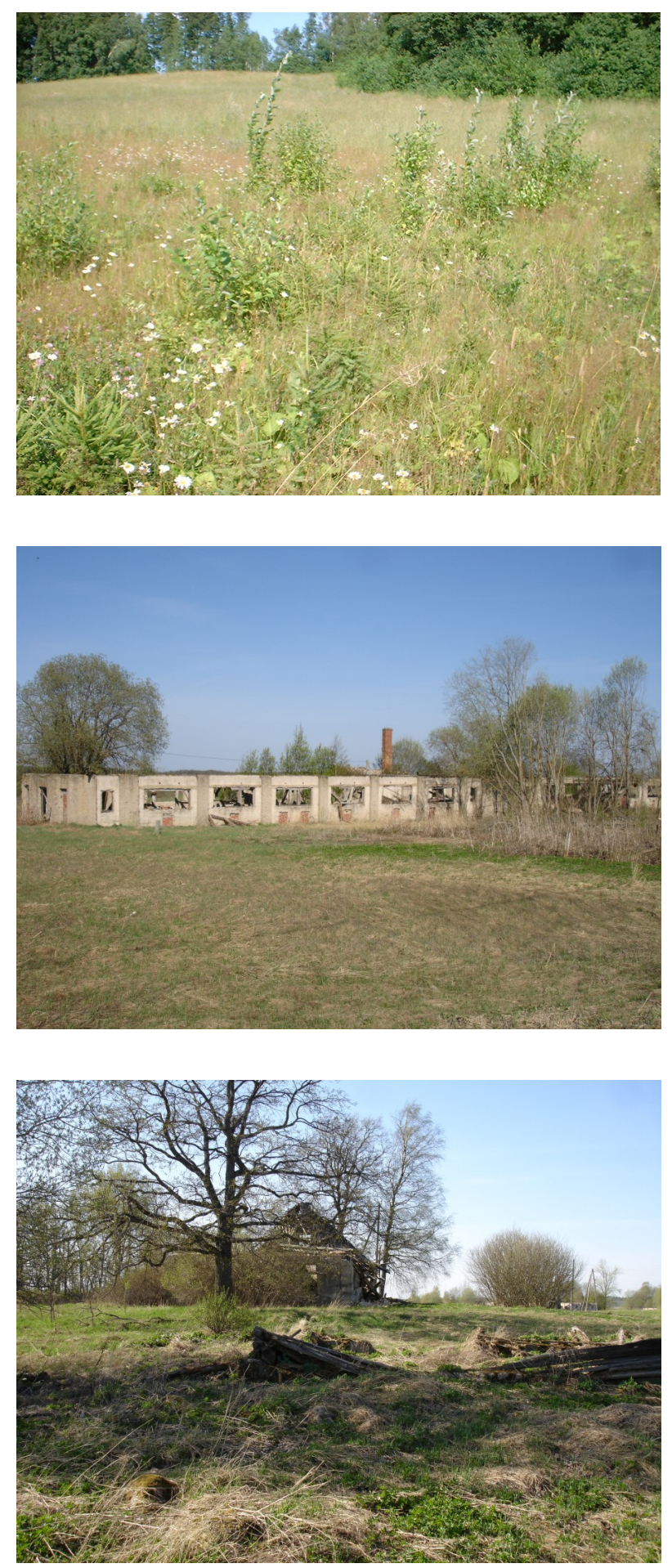

Figure 10: Some examples of the results of depopulation and land abandonment in Latvia: a) a field no longer cultivated, becoming colonised by trees; b) ruined buildings following the dismantling of the collective farm system; c) an old farmhouse which has collapsed following abandonment. All examples from Dzerbene pagast, Latvia (Source: Simon Bell). 
from the coast and it produces a mixed landscape where the clear distinction between dense urban development and broad rural areas has become blurred by numbers of suburban and exurban suburb-like developments interspersed with irrigated golf courses. This results in impacts on the environment such as water demand for human consumption and irrigation, loss of soil and increased salinisation, fragmentation of habitats, creation of gated communities and other leisure landscapes with restricted access and demand for other features such as shopping centres and infrastructure (Zasada et al., 2010). Figure 11 shows the distribution of foreign EU citizens over 64 years of age in the Alicante region, with strong coastal density pattern very evident. Figure 12 shows some of the typical landscape elements created as a result of international retirement migration.

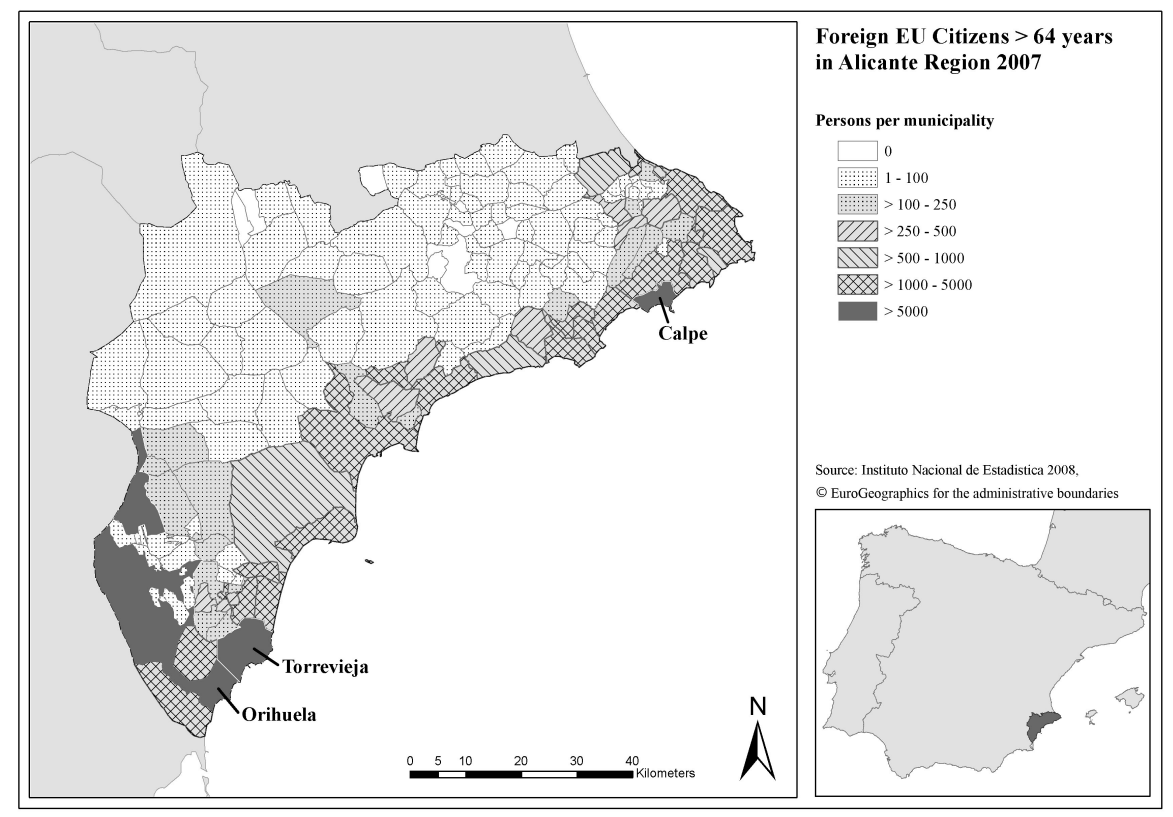

Figure 11: A map showing the density of retired people along the coast of the Alicante region in Spain (Source: Zasada et al., 2010).

\subsection{Urban growth in Lisbon as a result of immigration}

Over the past forty years Portugal has seen significant immigration from the African ex-colonies, Brazil and more recently Eastern Europe. The Cape Verdeans were the first group to arrive in the late 1960s, followed by the Brazilians in the 1990s, and more recently the Ukrainians in the beginning of 2000. According to the latest statistics these three nationalities constituted the three main communities (SEF, 2010). The migrants mainly come to work in low-status and low-skilled service jobs, or the so called 3D jobs (dirty, dangerous and difficult) (Fonseca et al., 2005; Marques and Góis, 2007) and many remain quite poor. The push factors are unemployment and poverty at home while the pull factors are availability of jobs, better prospects for the future, family reunion, social networks and historical links. In 2001, more than half of the immigrant population was living in Lisbon Metropolitan Area (Fonseca, 2003) and due to social and family networks new arrivals tend therefore to gravitate towards locations where their compatriots are to be found, which creates areas within the city where these ethnic groups mainly settle. In the late 1960s and 1970s, Lisbon Metropolitan area started its suburbanisation process with the establishment of unofficial housing in the outskirts of Lisbon in order to accommodate not only the influx of 

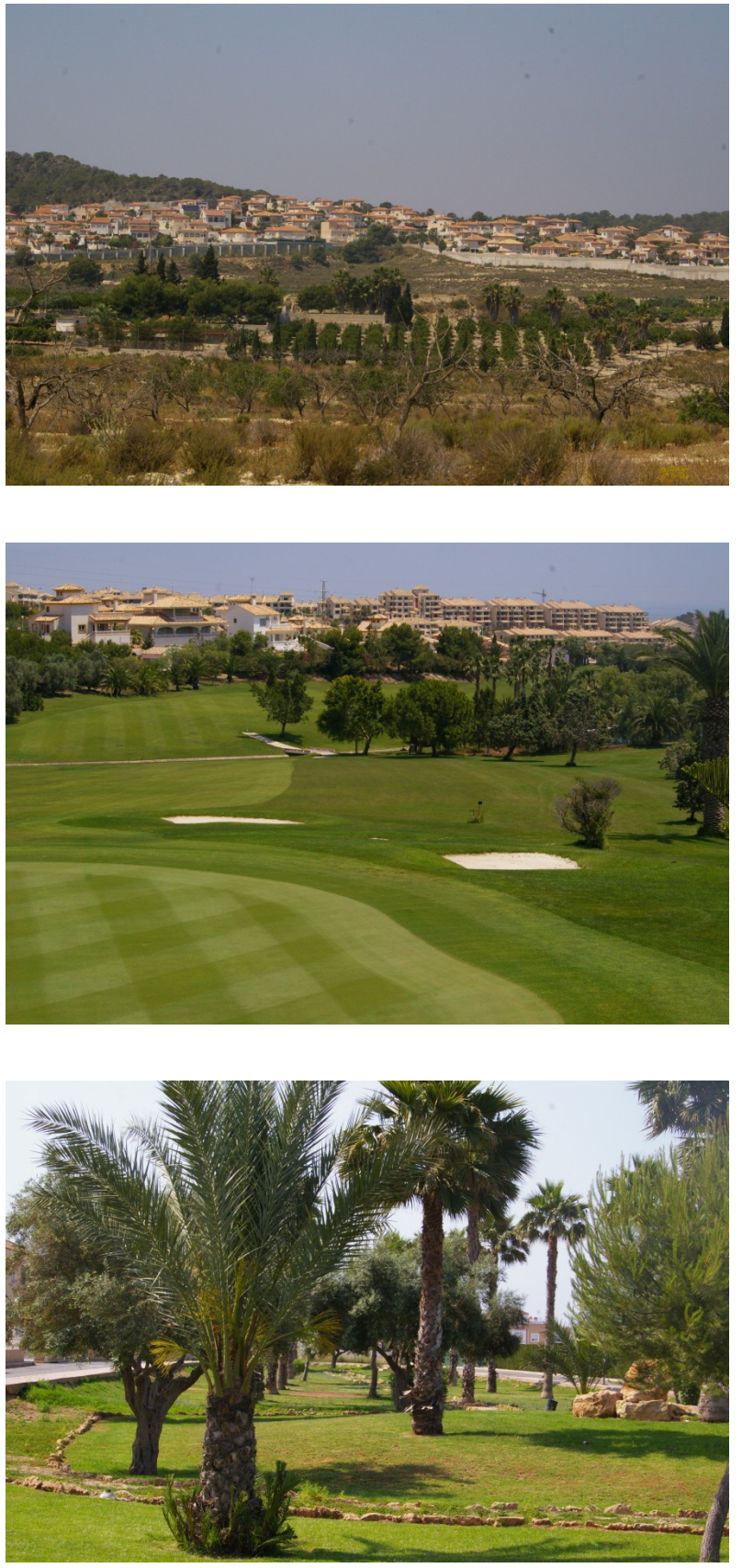

Figure 12: Some examples of development and associated features resulting from international retirement migration in the Alicante region of Spain: a) an extra-urban "urbanización" housing development surrounded by traditional landscape elements; b) an "urbanización" next to a highly manicured and irrigated golf course; c) an example of highly manicured and water intensive non-native ornamental planting (Source: Ingo Zasada). 
inland migrants from rural areas, but also international migrants from ex-African colonies who built their houses in shanty towns on public land (Castela, 2007). These areas grew outside all the planning regulations (alignments, density, heights, etc.) and without infrastructure, leading to poor environments and poor housing condition (Malheiros and Vala, 2004).

Cova da Moura neighourhood is one example of this unplanned and illegal genesis (Figures 13a and 13b). Two thirds of the resident population in this area have a foreign background (Mendes, 2008), mainly immigrants from Cape Verde and their descendents, who have, over time, settled in and developed their own unofficial quarters. The southern part of this neighbourhood characterised by densely built informal houses in very poor structural conditions, narrow streets, lack of green spaces, little infrastructure and few amenities (Horta, 2008; Mendes, 2008), represents, to a certain degree, a rupture in the urban fabric, being characteristically different from its surroundings. Apart from its morphological and physical problems, the neighbourhood is also known for its social problems. The majority of the working population has a low income and low skill jobs: men tend to work in the construction sector, while women are employed in cleaning and domestic jobs (Horta, 2008). Over recent years the neighbourhood has also been characterised by the media as an unsafe and criminal place, creating the image of a "black ghetto" with an unemployed and troublesome young population (Horta, 2008).

Other areas of the metropolitan area have not developed ad hoc like the district described above but have been filled with poor quality public social housing. These neighbourhoods are often segregated spaces, packed with a low income population and vulnerable groups. The monotony of construction, the similarity of the buildings, colour schemes, facades; the inadequacy of open spaces, the low quality of the social environment, the lack of facilities and amenities (Augusto, 2000) lead to a feeling of exclusion (Figure 13c).

Although legalisation and urban rehabilitation programmes started to take place during the 1990s in order to clean the slums, revitalise and improve the living and social conditions of some problematic neighbourhoods (Malheiros and Vala, 2004), the signs in the landscape of this unplanned suburbanisation and migratory movements are still visible. 

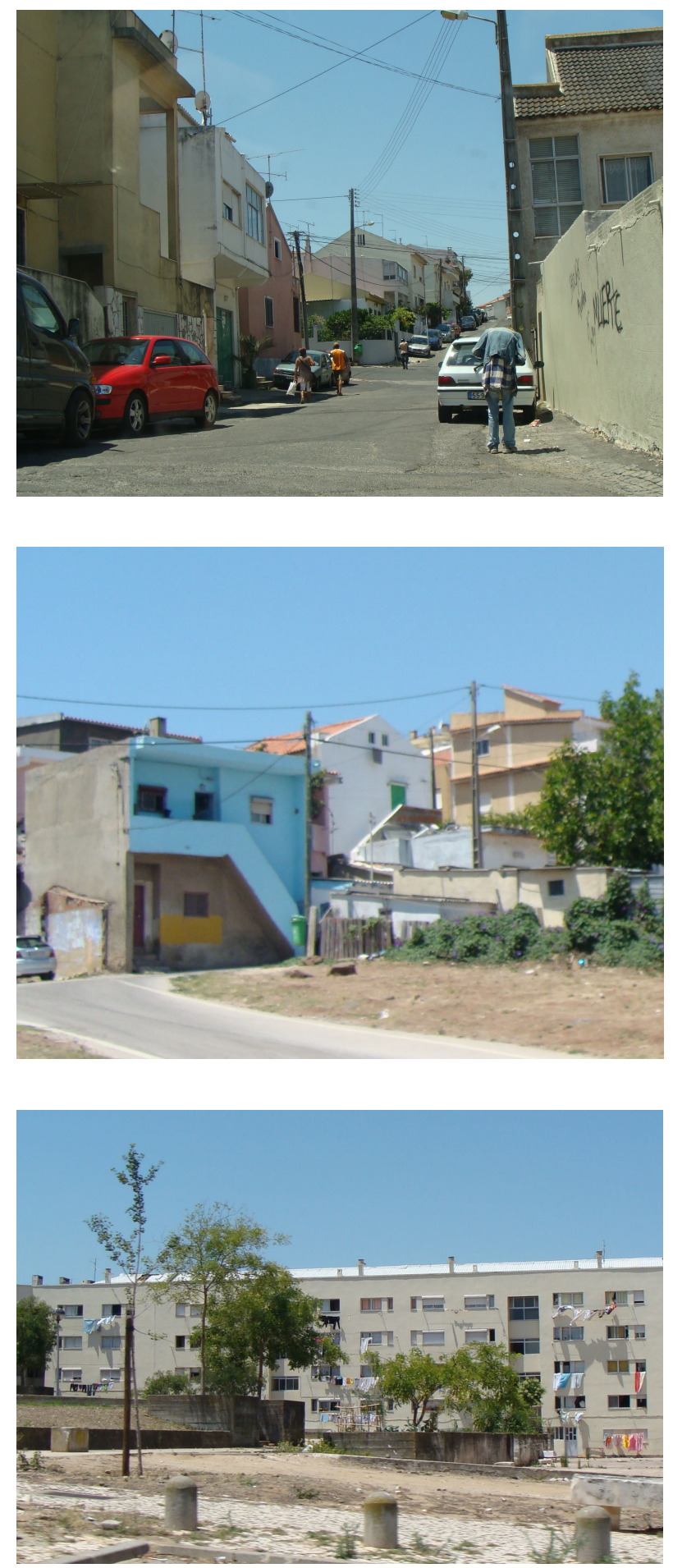

Figure 13: Some examples of residential areas occupied by migrants from Cape Verde in Lisbon, Portugal: a \& b) a poor area of informally developed and unplanned housing at Cova da Moura, Lisbon; c) social housing erected for poor immigrants near Cova da Moura. (Source: Eva Silveirinha de Oliveira). 


\section{Conclusions}

This study, using the limited available data has nevertheless been able to determine some important aspects of the way that migration is linked to land use change. The push-pull model for migration shows that many factors are at work and that Europe is a very dynamic region as far as migration is concerned. The effects on ethnicity are most obvious, especially when significant numbers of people from other global regions immigrate into Europe and create greater diversity of ethnicity, religion and culture. The pattern of this immigration is closely tied to factors such as the countries which were former colonial powers also being the most attractive destinations, as well as the presence of existing immigrant or ethnic communities which provide initial social support and community networks. Within Europe it is the east to west labour migration which is such a topical feature but the long term pattern is less obvious as many of these migrants are temporary. Ageing also manifests itself visibly in connection with various forms of national or international retirement migration. This, whether moving from a city to the countryside, moving from a city to the coast or moving from a northern country to a southern one, is a significant recent phenomenon. Such movements place added pressure on health and social care in the places where older people move to live. Another issue of ageing which is much less visible is that of old people left behind in abandoned rural areas with poor housing and lack of services.

As noted earlier, the increase in non-EU immigration could, with the increased population in ghetto areas or similar concentrations of ethnic minorities living in potentially still relatively deprived conditions, have important political and social repercussions. Based on the notion of environmental supportiveness, previously discussed, concerns over social cohesion, social support, educational attainments and other socio-economic aspects demand attention in future, especially in those countries which are the more significant attractors of migrants. This has many implications for urban development, housing policies, provision of education and other services, crime and policing - factors that have direct implications for peoples' quality of life. If a 'balance' can be achieved between the push and pull factors, in terms of the attractions for and impediments to migration in order to result in both increased well-being and sustainable land use management practices then a more holistic understanding of these processes is necessary. Environment-person processes, in this sense need to be contextualised in relation to particular flows, locations, and socio-demographic aspects of migration.

One of the interesting aspects to come to light in terms of land use change through migration pressures is the fact that it can operate in two ways at once - the changes occurring where the migrant comes from - such as rural land abandonment - and where the emigrants travel to - such as an increase in density of population and of multi-occupied houses. This "two country model" should not be surprising and is understood by economists but so far has not been brought out in the migration literature which has been largely interested in social, demographic or political factors and not with land use change.

For a number of reasons, not least the absence of much hard data, this study has major limitations which can only be overcome when and if more comprehensive data becomes available. Nevertheless, as an attempt to show the effects of these social factors as drivers of land use change it achieves some significant results. The identification of linkages between specific migration processes and land use change illustrated here shows that with further research, including the study of specific migrating groups in both the country of origin and the country(ies) of destination, offers potential to develop much more sophisticated models and projections. Over the last 50 or 60 years, as the literature review shows, patterns of migration have changed dramatically. Europe used to be a net out-migrating area and the labour flows were restricted. The Iron Curtain cut off large sections of Europe from each other. Now, with the enlarged EU, with globalisation, with the removal of internal borders in most of Europe, with the need to increase competitiveness and with cheap travel around the world it has become easier than ever before as well as more attractive for different forms 
of migration to take place. The effects of this are all around and politicians in many countries are making this a bigger issue. With more harmonisation of data resolved to common spatial scales at a European level it should be possible to understand these shifts and to formulate policies to manage them. The recognition that there is a two-country model in migration and land use change as well as economics should also enable better connections between the two phenomena to be made. Social policy and land use policy cannot be viewed as two separate aspects where migration is concerned. This paper helps to bring these aspects into sharper focus. 


\section{References}

Agarwal, C., Green, G.M., Grove, J.M., Evans, T.P. and Schweik, C.M. (2003), "A Review and Assessment of Land Use Change Models: Dynamics of Space, Time, and Human Choice", in Parks, B.O., K.M., Clarke and M.P., Crane, eds., Proceedings of the 4 th International Conference on Integrating Geographic Information Systems and Environmental Modeling: Problems, Prospectus, and Needs for Research (GIS/EM4), Banff, Alberta, Canada, September 2-8, 2000, Boulder; Denver (University of Colorado; U.S. Geological Survey; National Geophysical Data Center). URL (accessed 27 July 2010):

http://www.colorado.edu/research/cires/banff/pubpapers/20/. (Cited on page 6.)

Antrop, M. (2005), "Why landscapes of the past are important for the future", Landscape and Urban Planning, 70(1-2): 21-34, [DOI]. (Cited on page 6.)

Arango, J. (2000), "Explaining Migration: A Critical View", International Social Science Journal, 52: 283-296, [DOI]. (Cited on page 7.)

Arapoglou, V.P. (2006), "Immigration, Segregation, and Urban development in Athens: The Relevance of the LA Debate for Southern European Metropolises", Greek Review of Social Research, 121(special issue): 11-38. (Cited on pages 9, 10, and 20.)

Arapoglou, V.P. and Sayas, J. (2009), "New Facets of Urban Segregation in Southern Europe: Gender, Migration and Social Class Change in Athens", European Urban and Regional Studies, 16(4): 345-362, [DOI]. (Cited on page 21.)

Augusto, N.M. (2000), "Habitação social - da intenção de inserção à ampliação da exclusão", in IV Congresso Português de Sociologia - Sociedade Portugesa: Passados Recentes, Futuros Próximos, Coimbra, 17-19 de Abril 2000, Lisbon (Potuguese Sociological Association). URL (accessed 27 July 2010): http://www.aps.pt/cms/docs_prv/docs/DPR462df3cd04e3f_1.PDF. (Cited on page 39.)

Bell, S. (2009a), Landscape Change, Landscape Perception and The Latvian Countryside, Ph.D. Thesis, Estonian University of Life Sciences, Tartu. Online version (accessed 27 July 2010): http://hdl.handle.net/10492/89. (Cited on page 34.)

Bell, S. (2009b), "The shadow of the kolkhoz: Soviet ruins in the Baltic countryside", in Ghersi, A. and Mazzino, F., eds., Landscape 6 Ruins: Planning and Design for the regeneration of derelict places, Proceedings of the 2009 European Council of Landscape Architecture Schools (ECLAS) conference, September 23-26, 2009, Genova, Florence (Alinea Editrice). (Cited on page 34.)

Bell, S., Peneze, Z., Nikodemus, O. and Montarzino, A. (2008), "Perceptions of the Latvian landscape during social and economic transitions", Place and Location, VI: 239-256. Online version (accessed 27 July 2010): http://www.eki.ee/km/place/pdf/kp6_17_belljt.pdf. (Cited on page 34.)

Bell, S., Montarzino, A., Aspinall, P., Peneze, Z. and Nikodemus, O. (2009a), "Rural society, social inclusion and landscape change in central and eastern Europe: a case study of Latvia", Sociologia Ruralis, 49(3): 295-326, [DOI]. (Cited on page 34.)

Bell, S., Nikodemus, O., Peneze, Z. and Kruze, I. (2009b), "Management of cultural landscapes: what does this mean in the Former Soviet Union? A case study from Latvia", Landscape Research, 34(4): 425-455, [DOI]. (Cited on page 34.)

Bodaar, A. and Rath, J. (2005), "Cities, Diversity and Public Space", Metropolis World Bulletin, 5: 3-5. (Cited on pages 9 and 10.) 
Bolesta, A. (2004), "New Immigration Policy in Europe", TIGER Working Paper series, 70, Warsaw (TIGER Institute). Online version (accessed 10 August 2010): http://www.tiger.edu.pl/english/publikacje/working.htm. (Cited on page 14.)

Borkert, M., Pérez, A.M., Scott, S. and De Tona, C. (2006), "Introduction: Understanding Migration Research: (Across National and Academic Boundaries) in Europe", Forum: Qualitative Social Research, 7, 3. URL (accessed 27 July 2010):

http://www.qualitative-research.net/index.php/fqs/article/view/132. (Cited on page 6.)

Boswell, C. (2005), "Migration in Europe", RS4, Geneva (Global Comission on International Migration (GCIM)). URL (accessed 27 July 2010):

http://www.gcim.org/attachements/RS4.pdf. Prepared for the Policy Analysis and Research Programme of the Global Commission on International Migration, Regional Studies. (Cited on pages 6 and 14.)

Bürgi, M., Hersperger, A.M. and Schneeberger, N. (2004), "Driving forces of landscape change current and new directions", Landscape Ecology, 19(8): 857-868, [DOI]. (Cited on page 6.)

Castela, T. (2007), "Urban Planning Practices and the Economy of Spatial Illegalisms: 'Clandestine' Neighborhoods in the Lisbon Area, 1960-2000", First International Conference of Young Urban Researchers (FICYUrb), June 11-12, 2007, Lisbon, conference paper. (Cited on page 39.)

Castles, S. (2000), "International Migration at the Beginning of the Twenty-First Century: Global Trends and Issues", International Social Science Journal, 165: 269-281, [DOI]. (Cited on pages 6 and 14.)

Castles, S. (2003), "Towards a Sociology of Forced Migration and Social Transformation", Sociology, 37(1): 13-34, [DOI]. (Cited on page 17.)

Castles, S. (2005), Globalização, Transnacionalismo e Novos Fluxos Migratórios: dos trabalhadores convidados às migrações globais, Lisboa (Fim de Século). (Cited on pages 16 and 17.)

Champion, T. (2004), "Ageing and Migration Trends", The English Regions and Demographic Ageing: Key Trends and Issues, Sheffield, 13 December 2004, conference paper. (Cited on page 19.)

Deurloo, M.C. and Musterd, S. (1998), "Ethnic Clusters in Amsterdam, 1994-96: A Micro-area Analysis", Urban Studies, 35(3): 385-396, [DOI]. (Cited on pages 9 and 20.)

EEA (2006), "Urban sprawl in Europe: The ignored challenge", EEA Report, 10/2006, Copenhagen (European Environment Agency). Online version (accessed 27 July 2010):

http://www.eea.europa.eu/publications/eea_report_2006_10. (Cited on pages 9, 10, 12, 18, and 19.)

ESPON (2005), "ESPON project 1.1.4: The Spatial Effects of Demographic Trends and Migration (Final Report)", Johansson, M. and Rauhut, D., eds., Luxembourg (ITPS/ESPON). URL (accessed 27 July 2010):

http://www.espon.eu/main/Menu_Projects/Menu_ESPON2006Projects/Menu_ ThematicProjects/demographictrends.html. (Cited on pages 13 and 20.)

Eurostat (2007), "Europe in Figures - Eurostat yearbook 2006-07", Luxembourg (Eurostat). Online version (accessed 10 August 2010):

http://epp.eurostat.ec.europa.eu/portal/page/portal/product_details/ publication?p_product_code=KS-CD-06-001. (Cited on pages 14 and 22.)

Living Reviews in Landscape Research

http: //www. livingreviews.org/lrlr-2010-2 
Fahey, T. and Fanning, B. (2010), "Immigration and Socio-spatial Segregation in Dublin, 19962006", Urban Studies, 47(8): 1625-1642, [DOI]. (Cited on page 12.)

Favell, A. (2003), "Eurostars and Eurocities: Towards a Sociology of Free Moving Professionals in Western Europe", Working Paper, 71, San Diego (Center for Comparative Immigration Studies, University of California). URL (accessed 27 July 2010): http://www.ccis-ucsd.org/PUBLICATIONS/wrkg71.pdf. (Cited on pages 9 and 10.)

Figueiredo, J.M. (2005), Fluxos Migratórios e Cooperação para o Desenvolvimento: Realidades compatíveis no contexto Europeu?, Ph.D. Thesis, Universidade Técnica de Lisboa, Lisbon. Online version (accessed 27 July 2010):

http://www.oi.acidi.gov.pt/modules.php?name=News\&file=article\&sid=856. (Cited on pages 7 and 16.)

Fonseca, M.L. (2001), "Urban Social Futures - Immigration and Spatial Change: the Lisbon experience", Urban Futures seminar, Södertälje, Sweden, May 9-12, 2001, conference paper. (Cited on pages 9,10 , and 20 .)

Fonseca, M.L. (2003), "Integração dos imigrantes: estratégias e protagonistas", I Congresso Imigração em Portugal - Diversidade, Cidadania e Integração, Lisboa, Fundação Calouste Gulbenkian, 18-19 December 2003, conference paper. Online version (accessed 27 July 2010): http://www.ceg.ul.pt/mcm/ICongressoLF.htm. (Cited on page 37.)

Fonseca, M.L., Malheiros, J.M. and Silva, S. (2005), "Portugal", in Niessen, J., Schibel, Y. and Thompson, C., eds., Current Immigration Debates in Europe: A Publication of the European Migration Dialogue, Brussels (Migration Policy Group), 2nd edn. Online version (accessed 27 July 2010):

http://www.migpolgroup.org/public/docs/141.EMD_Portugal_2005.pdf. (Cited on page 37.)

Fortuijn, J.D., Musterd, S. and Ostendorf, W. (1998), "International Migration and Ethnic Segregation: Impacts on Urban Areas - Introduction", Urban Studies, 35(3): 367-370, [DOI]. (Cited on page 20.)

Gallotti, M. (2009), "The Gender Dimension of Domestic Work in Western Europe", International Migration Papers, 96, Geneva (International Labour Organization). Online version (accessed 27 July 2010):

http://www.ilo.org/public/english/protection/migrant/download/imp/imp96.pdf. (Cited on page 20.)

Gaspar, J. (2001), "Urban economic features: a comment", Urban Futures seminar, Södertälje, Sweden, May 9-12, 2001, conference paper. (Cited on page 20.)

GISCO (2009), "Maps", Luxembourg (Eurostat). Online version (accessed 4 August 2010): http://epp.eurostat.ec.europa.eu/portal/page/portal/gisco/maps_posters/maps. (Cited on pages 14, 15, 23, and 24.)

Godoy, L.D. (2002), "La inmigración en Europa: realidades y políticas - Documento de Trabajo 02-18", 02-18, Madrid (Consejo Superior de Investigaciones Cientificas (CSIC)). URL (accessed 27 July 2010):

http://www.iesam.csic.es/doctrab2/dt-0218.pdf. (Cited on page 6.)

Greenwood, M.J. and Hunt, G.L. (2003), "The Early History of Migration Research", International Regional Science Review, 26(1): 3-37, [DOI]. (Cited on page 6.) 
Hardill, I., Spradbery, J., Arnold-Boakes, J. and Marrugat, M.L. (2004), "Retirement migration: the other story. Issues facing English speaking migrants who retire to Spain", RSA Conference, Europe at the Margins: EU Regional Policy, Peripherality and Rurality, April 16th 2004, conference paper. (Cited on page 19.)

Hårsman, B. (2006), "Ethnic diversity and spatial segregation in the Stockholm region", Urban Studies, 43(8): 1341-1364, [DOI]. (Cited on pages 9, 10, and 20.)

Horta, A.P.B. (2008), "Que Cidadania? Etnicidade, Identidades Locais e Agenciamento na Periferia de Lisboa", VI Congresso Português de Sociologia, Mundos Sociais: Saberes e Práticas, Lisboa, 25-28 de Junho de 2008, conference paper. Online version (accessed 27 July 2010): http://www.aps.pt/vicongresso/pdfs/541.pdf. (Cited on page 39.)

ICFTU (2003), "Migrants in European Agriculture: open season for exploitation", Trade Union World Briefing, 7, Brussels (ICFTU). Online version (accessed 27 July 2010): http://www.icftu.org/displaydocument.asp?Index=991218845. (Cited on page 9.)

Kaplan, D.H. and Woodhouse, K. (2004), "Research in Ethnic Segregation I: Causal factors", Urban Geography, 25(6): 579-585, [DOI]. (Cited on page 20.)

King, R., Warnes, A.M. and Williams, A.M. (1998), "International Retirement Migration in Europe", International Journal of Population Geography, 4(2): 91-111, [DOI]. (Cited on pages 9, $10,11,17$, and 18.)

Kontuly, T. and Tammaru, T. (2006), "Population Subgroups Responsible for New Urbanization and Suburbanization in Estonia", European Urban and Regional Studies, 13(4): 319-336, [DOI]. (Cited on pages 11 and 19.)

Kröhnert, S., Hoßmann, I. and Klingholz, R. (2008), Europe's Demographic Future: Growing Regional Imbalances, Berlin (The Berlin Institute of Population and Development). (Cited on pages $13,18,20$, and 30.)

Kubursi, A. (2006), "The Economics of Migration and Remittances Under Globalization", The Informal Preparatory Meeting on the Theme of the 2006 High Level Segment, United Nations Headquarters, New York, 4-5 April 2006, conference paper. Online version (accessed 27 July 2010):

http://www.un.org/docs/ecosoc/meetings/2006/hls2006/Preparatory/Statements/

Kubursi_RT6.pdf. (Cited on pages 7 and 16.)

Labrianidis, L. and Sykas, T. (2009), "Migrants, Economic Mobility and Socio-Economic Change in Rural Areas: The Case of Greece", European Urban and Regional Studies, 16(3): 237-256, [DOI]. (Cited on pages 9, 10, and 28.)

Lambin, E.F., Turner, B.L., Geist, H.J., Agbola, S.B., Angelsen, A., Bruce, J.W., Coomes, O.T., Dirzo, R., Fischer, G., Folke, C., George, P.S., Homewood, K., Imbernon, J., Leemans, R., Li, X., Moran, E.F., Mortimore, M., Ramakrishnan, P.S., Richards, J.F., Skånes, H., Steffen, W., Stone, G.D., Svedin, U., Veldkamp, T.A., Vogel, C. and Xu, J. (2001), "The causes of landuse and land-cover change: moving beyond the myths", Global Environmental Change, 11(4): 261-269, [DOI]. (Cited on page 6.)

Lardiés Bosque, R. and Castro Romero, M. (2002), "Inmigración extranjera en Cataluña: las nuevas motivaciones de los ciudadanos europeos para el desplazamiento y la atracción del turismo", Scripta Nova, VI(119), 127. URL (accessed 27 July 2010):

http://www.ub.es/geocrit/sn/sn119127.htm. (Cited on pages 9, 11, and 17.)

Living Reviews in Landscape Research

http://www. livingreviews.org/lrlr-2010-2 
López, E., Bocco, G., Mendoza, M., Velázquez, A. and Aguirre-Rivera, J.R. (2006), "Peasant emigration and land-use change at the watershed level: A GIS-based approach in Central Mexico", Agricultural Systems, 90(1-3): 62-78, [DOI]. (Cited on page 6.)

Lowe, P. and Stephenson, M. (2003), "Demographic Ageing and Rural Areas", Paper presented at the Regions for All Ages Conference, 11 March 2003, Birmingham, conference paper. (Cited on page 19.)

Malgesini, G. (2006), "Immigrants from Urban to Rural Areas in Spain: The Impact of Transnationalism", online resource, Centro de Investigación para la Paz. URL (accessed 27 July 2010): http://www.cipresearch.fuhem.es/pazyseguridad/docs/Immigrants $\% 20$ from\%20urban\% 20to\%20rural\%20areas\%20in\%20Spain\%20ING.pdf. (Cited on pages 9, 10, and 20.)

Malheiros, J. (2002), "Ethni-cities: Residential Patterns in the Northern European and Mediterranean Metropolises - Implications for Policy Design", International Journal of Population Geography, 8: 107-134, [DOI]. (Cited on pages 9, 10, and 20.)

Malheiros, J.M. and Vala, F. (2004), "Immigration and city change: the Lisbon metropolis at the turn of the twentieth century", Journal of Ethnic and Migration Studies, 30(6): 1065-1086, [DOI]. (Cited on pages 9, 10, 20, and 39.)

Marques, J.C. and Góis, P. (2007), "Ukrainian migration to Portugal. From non-existence to the top three immigrant groups", project homepage, Multicultural Center Prague. URL (accessed 28 July 2010):

http://www.migrationonline.cz/e-library/?x=1963795. (Cited on page 37.)

Massey, D. (2003), "Patterns and Processes of International Migration in the 21st Century", African Migration in Comparative Perspective, Johannesburg, 4 - 7 June 2003, conference paper. Online version (accessed 27 July 2010): http://pum.princeton.edu/pumconference/papers/1-Massey.pdf. (Cited on page 7.)

Massey, D.S., Arango, J., Hugo, G., Kouaouci, A., Pellegrino, A. and Taylor, J.E. (1993), "Theories of International Migration: A Review and Appraisal", Population and Development Review, 19 (3): 431-466, [DOI]. (Cited on page 9.)

Massey, D.S., Arango, J., Hugo, G., Kouaouci, A., Pellegrino, A. and Taylor, J.E. (2005), Worlds in Motion: Understanding International Migration at the End of the Millennium, International Studies in Demography, Oxford; New York (Clarendon Press). Google Books. (Cited on page 9.)

Mendes, L. (2008), "Urbanização clandestina e fragmentação socio-espacial urbana contemporânea: o Bairro da Cova da Moura na periferia de Lisboa", Revista da Faculdade de Letras: Geografia, II: 57-82. URL (accessed 27 July 2010):

http://ler.letras.up.pt/uploads/ficheiros/6372.pdf. (Cited on page 39.)

Mingione, E. (2009), "Family, Welfare and Districts: The Local Impact of New Migrants in Italy", European Urban and Regional Studies, 16(3): 225-236, [DOI]. (Cited on page 21.)

Münz, R. and Straubhaar, T. (2006), "Migrants and the European Labor Market", in Papademetriou, D.G., ed., Europe and Its Immigrants in the 21st Century: A New Deal or a Continuing Dialogue of the Deaf?, pp. 121-153, Washington, DC (Migration Policy Institute and Luso-American Foundation). (Cited on page 20.)

Peixoto, J. (2001), "The International Mobility of Highly Skilled Workers in Transnational Corporations: The Macro and Micro Factors of the Organizational Migration of Cadres", International Migration Review, 35(4): 1030-1053, [DOI]. (Cited on page 16.) 
Peixoto, J. (2004), "As Teorias Explicativas das Migrações: Teorias Micro e Macro-Sociológicas", SOCIUS Working Papers, 11/2004, Lisbon (SOCIUS). URL (accessed 27 July 2010): http://pascal.iseg.utl.pt/ socius/publicacoes/wp/wp200411.pdf. (Cited on page 7.)

Perruchoud, R., ed. (2004), Glossary on Migration, International Migration Law, 1, Geneva (International Organization for Migration). (Cited on page 7.)

Petrov, L.O. and Lavalle, C. (2006), "Modelling future land use changes in Europe. Preparations for the case study Algarve region, Portugal", EUR 22559 EN, Luxembourg (European Commission, DG-Joint Research Centre and Institute for Environment and Sustainability). (Cited on pages 10, 17, and 18.)

Portes, A., ed. (1995), The Economic Sociology of Immigration: Essays on Networks, Ethicity, and Entrepreneurship, New York (Russel Sage Foundation). Google Books. (Cited on pages 7 and 9.)

Portes, A. and Böröcz, J. (1989), "Contemporary Immigration: Theoretical Perspectives on Its Determinants and Modes of Incorporation", International Migration Review, 23(3): 606-630, [DOI]. (Cited on pages 7 and 9.)

Rodríguez, V., Fernández-Mayoralas, G. and Rojo, F. (1998), "European Retirees on the Costa del Sol: A Cross-National Comparison", International Journal of Population Geography, 4(2): 183-200, [DOI]. (Cited on pages 10, 17, and 18.)

SEF (2010), "Relatório de Imigração, Fronteiras e Asilo - 2009", Barcarena (SEF). Online version (accessed 4 August 2010): http://sefstat.sef.pt/Docs/Rifa_2009.pdf. (Cited on page 37.)

Shon, J.-L.P.K. (2010), “The Ambivalent Nature of Ethnic Segregation in France's Disadvantaged Neighbourhoods", Urban Studies, 47(8): 1603-1623, [DOI]. (Cited on page 21.)

Sugiyama, T. and Ward Thompson, C. (2007), "Outdoor environments, activity and the well-being of older people: Conceptualising environmental support", Environment and Planning A, 39(8): 1943-1960, [DOI]. (Cited on page 7.)

UNFPA (2007), "State of World Population 2007: Unleashing the Potential of Urban Growth", New York (United Nations Population Fund). Online version (accessed 27 July 2010): http://www.unfpa.org/public/home/publications/pid/408. (Cited on page 9.)

Vasileva, K. (2009), "Population and social conditions", Statistics in focus, 94, Luxembourg (Eurostat). URL (accessed 27 July 2010): http://epp.eurostat.ec.europa.eu/portal/page/portal/product_details/ publication?p_product_code=KS-SF-09-094. (Cited on page 20.)

White, P. (1998), "The Settlement Patterns of Developed World Migrants in London", Urban Studies, 35(10): 1725-1744, [DOI]. (Cited on page 9.)

Williams, A.M., King, R. and Warnes, T. (1997), "A place in the sun: international retirement migration from northern to southern Europe", European Urban and Regional Studies, 4(2): 115134, [DOI]. (Cited on page 34.)

Wood, R. and Handley, J. (2001), "Landscape Dynamics and the Management of Change", Landscape Research, 26(1): 45-54, [DOI]. (Cited on page 6.)

Living Reviews in Landscape Research

http://www. livingreviews . org/lrlr-2010-2 
Zasada, I., Alves, S., Müller, F.C., Piorr, A., Berges, R. and Bell, S. (2010), "International retirement migration in the Alicante region, Spain: process, spatial pattern and environmental impacts", Journal of Environmental Planning and Management, 53(1): 125-141, [DOI]. (Cited on pages 6 and 37.) 